\title{
Review \\ Driving CAR T Stem Cell Targeting in Acute Myeloid Leukemia: The Roads to Success
}

\author{
Ilaria M. Michelozzi *, Efstratios Kirtsios and Alice Giustacchini *(D)
}

check for updates

Citation: Michelozzi, I.M.; Kirtsios, E.; Giustacchini, A. Driving CAR T Stem Cell Targeting in Acute Myeloid Leukemia: The Roads to Success. Cancers 2021, 13, 2816. https:/ / doi.org/10.3390/cancers13112816

Academic Editor: Mhairi Copland

Received: 11 May 2021

Accepted: 2 June 2021

Published: 5 June 2021

Publisher's Note: MDPI stays neutral with regard to jurisdictional claims in published maps and institutional affiliations.

Copyright: (c) 2021 by the authors. Licensee MDPI, Basel, Switzerland. This article is an open access article distributed under the terms and conditions of the Creative Commons Attribution (CC BY) license (https:// creativecommons.org/licenses/by/ $4.0 /)$.
Molecular and Cellular Immunology Section, UCL Great Ormond Street Institute of Child Health, Zayed Centre for Research into Rare Disease in Children, London WC1N 1DZ, UK; efstratios.kirtsios.18@ucl.ac.uk

* Correspondence: i.michelozzi@ucl.ac.uk (I.M.M.); a.giustacchini@ucl.ac.uk (A.G.)

Simple Summary: Chimeric antigen receptor (CAR) T-cells are powerful therapeutic tools that have revolutionized the treatment of several hematological malignancies. However, their therapeutic application in acute myeloid leukemia (AML) remains challenging. In this review, the authors aimed to dissect how AML-leukemic stem cell and AML-bone marrow niche features can impact on the success of CAR T-cell therapy. The clinical implementation of some of the newly developed approaches discussed in this review may lead to the development of safe and effective CAR T-cell strategies for AML, accounting for the disease heterogeneity.

Abstract: Current treatment outcome for acute myeloid leukemia (AML) patients is unsatisfactory and characterized by high rates of relapse and poor overall survival. Increasing evidence points to a crucial role of leukemic stem cells (LSC) and the bone marrow (BM) leukemic niche, in which they reside, in AML evolution and chemoresistance. Thus, future strategies aiming at improving AML therapeutic protocols are likely to be directed against LSC and their niche. Chimeric antigen receptor (CAR) T-cells have been extremely successful in the treatment of relapsed/refractory acute lymphoblastic leukemia and B-cell non-Hodgkin lymphoma and comparable results in AML are highly desirable. At present, we are at the dawn of CAR T-cell application in AML, with several preclinical studies and few early phase clinical trials. However, the lack of leukemia-specific targets and the genetic and phenotypic heterogeneity of the disease combined with the leukemia-induced remodeling of the BM microenvironment are limiting CAR T-cell exploitation in AML. Here, we reviewed AML-LSC and AML-BM niche features in the context of their therapeutic targeting using CAR T-cells. We summarized recent progress in CAR T-cell application to the treatment of AML, and we discussed the remaining therapeutic challenges and promising novel strategies to overcome them.

Keywords: acute myeloid leukemia; leukemic stem cells; bone marrow niche; chimeric antigen receptor T-cells

\section{Introduction}

Acute myeloid leukemia (AML) is a life-threatening blood cancer characterized by the uncontrolled/abnormal proliferation of myeloblasts that accumulate mainly in bone marrow (BM) and peripheral blood [1].

With a patient's average age at diagnosis of 68 years [2], AML mostly affects adults.

Despite the recent progress made in AML diagnosis, risk stratification, and prognosis, treatments have not considerably changed over the last two decades. In particular, AML therapeutic pillars consist of an induction therapy, based on cytarabine and anthracycline, followed by a consolidation regimen, including chemotherapy and/or allogeneic stem cell transplantation, necessary to kill residual leukemic clones to prevent relapse [1,3]. Patients' survival is extremely poor, especially for the elderly ( $\geq 65$ years), only $30 \%$ of whom survive over 1 year post-diagnosis [1], with relapse rates ranging from $9 \%$ to $78 \%$ [4]. 
To date, the biological and clinical complexity of the disease, largely attributable to its molecular and phenotypic heterogeneity, hinders the development of a successful treatment for AML [5].

AML cell populations are organized in a hierarchical structure dominated by a rare and heterogeneous subset of cells [6-8], the so-called leukemic stem cells (LSC). LSC are capable of initiating and maintaining the disease [6] and have been shown to fuel disease relapse due to their intrinsic and extrinsic (BM microenvironment-mediated) chemoresistance properties [9-11].

Due to the central role of LSC in AML pathogenesis and progression, their therapeutic targeting and elimination are imperative in order to improve patient's outcome [5].

Recently, the technological progress in high-throughput single-cell approaches offered an unprecedented resolution on tumor heterogeneity. Indeed, single-cell analyses provide a powerful tool not only to dissect clonal evolution and hierarchical structure of hematological disorders [12-17], but also to unravel the unique features of malignant stem cells and their BM niche dependencies [14-16,18,19]. Results from single-cell analyses have the potential to gain new insights into the pathogenesis of several hematological diseases and identify new candidate molecules for targeted therapies [12,14-16,18,19].

Novel therapies are currently under preclinical and clinical investigation in AML, as extensively described in [20-22], and they mainly aim at targeting LSC, the molecular processes altered in LSC and AML blasts, and their interplay with the BM microenvironment.

While recently developed small-molecule inhibitors have a role in subsets of AML (e.g., IDH1/2 and FLT3 mutated) [20], because of the genetic heterogeneity of this disease they are unlikely to be broadly applicable.

One strategy that is presently being explored with limited success [21] but with a potential broader applicability involves the application of chimeric antigen receptor (CAR) T-cells.

CAR T-cells, which uniquely combine the specificity of a monoclonal antibody with the efficacy of a cytotoxic T-cell, have revolutionized the treatment of several hematological malignancies, especially relapsed/refractory acute lymphoblastic leukemia (ALL) and B-cell non-Hodgkin lymphoma [23].

Comparable applications in AML would be highly beneficial. However, the development of immunotherapeutic strategies harnessing the power of engineered T-cells against AML has been hindered by the disease heterogeneity and complicated by the chemo-resistant and immune-evasive properties of AML-LSC and by the AML-BM niche characteristics.

Herein, we reviewed the role of AML-LSC and the leukemia-associated BM remodeling in treatment escape. We summarized the recent developments in the application of CAR T-cells to the treatment of AML and we discussed the main challenges ahead, as well as potential novel strategies to progress toward successful CAR T-cell therapy for AML.

\section{The Role of LSC and the BM Microenvironment in AML}

AML-LSC were first identified and functionally defined as the only cells capable of initiating and maintaining the disease in xenotransplantation settings, due to their unique self-renewal and proliferation properties [6,24]. Since then, AML-LSC biological and molecular features have been extensively studied to identify their therapeutic vulnerabilities and determine how they contribute to AML clinical complexity. LSC features are outlined in Figure 1. 


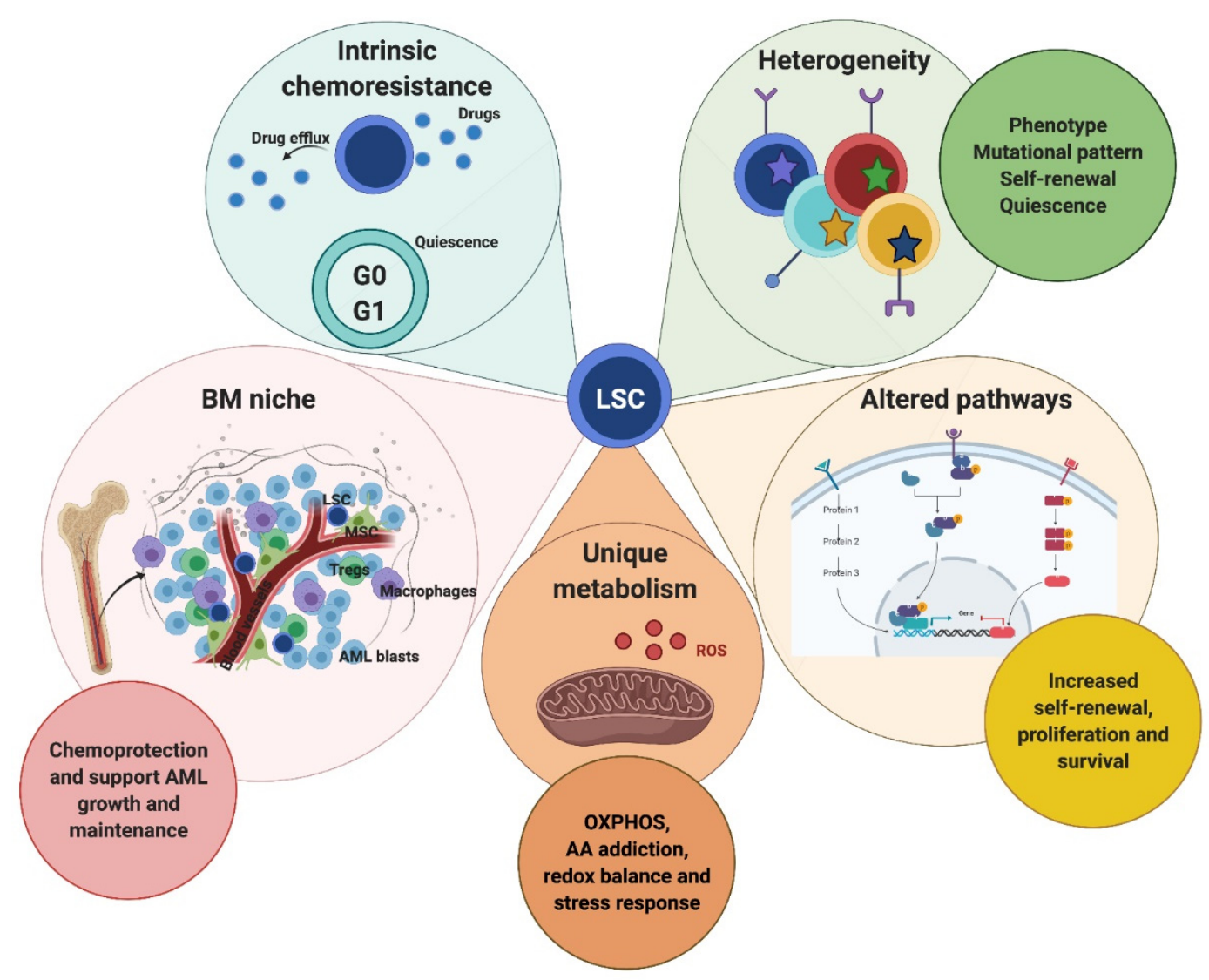

Figure 1. Summary of leukemic stem cell (LSC) distinctive features. LSC are characterized by phenotypic, mutational, self-renewal- and quiescence-related heterogeneity. This, in addition to intrinsic and extrinsic chemoresistance, could hamper acute myeloid leukemia (AML) treatment efficacy. The efflux pumps expressed on LSC surface and LSC quiescence determine their intrinsic drug resistance. Moreover, the AML-bone marrow (BM) niche represents a LSC cradle which supports AML cell expansion and survival providing chemoprotection. On the other hand, LSC exhibit unique metabolism and altered molecular pathways offering selective therapeutic targets. LSC, leukemic stem cells; BM, bone marrow; MSC, mesenchymal stromal cells; Tregs, regulatory T-cells; AML, acute myeloid leukemia; ROS, reactive oxygen species; OXPHOS, oxidative phosphorylation; AA, amino acids.

In the next sections, we discuss some of the key factors challenging AML-LSC therapeutic targeting: (1) their similarity with normal hematopoietic stem cells (HSC), (2) their heterogeneity, and (3) the leukemia-induced remodeling of the BM niche.

\subsection{LSC vs. HSC: Selective LSC-Targeted Eradication}

Since the AML hierarchical structure was first described, parallelisms with normal hematopoiesis have been extensively investigated.

Like HSC, LSC mainly reside within the BM [25], are highly quiescent, and are able to self-renew as well as to give rise to more mature cell subsets [9].

Similarly to HSC, LSC display increased chemoresistance, due to their intrinsic properties (such as their quiescent state and the increased expression of components of multi-drug efflux pumps) or to the leukemia supportive BM microenvironment $[9,25]$.

Furthermore, LSC and HSC share similar immunophenotypic patterns (e.g., CD13, CD33, CD71, CD99, CD117, CD133, CD200, CD244) and it is widely accepted that they both reside within the lineage negative (Lin-)CD34+CD38- compartment [21,26].

These shared features challenge the efficient discrimination between LSC (to be therapeutically targeted) and HSC (to be spared and rescued).

However, LSC display distinct antigenic, molecular, and metabolic traits that could render them selectively targetable. 
Several surface antigens have been shown to be preferentially expressed in LSC against HSC and thus proposed as potential biomarkers and therapeutic targets (e.g., CD25, CD32, CD44, CD47, CD96, CD123, TIM3, CLL1) [27]. Some of these markers are currently being evaluated as CAR T-cell targets, as discussed in the next paragraph of this review.

Differential gene expression analyses have also revealed LSC-specific signatures, including genes involved in various pathways, such as adherens junction, actin cytoskeleton organization, apoptosis, and MAPK, JAK-STAT, and Wnt signaling pathways [28].

Recently, new analytical methods based on the simultaneous detection of mutations and whole transcriptome at the single-cell level have allowed unprecedented resolution in discriminating between normal and malignant single stem cells within the same tumor [14-16,18].

The application of one of these single-cell integrated approaches in the AML context has revealed novel LSC-specific candidate surface markers encoded by CD36 and CD74 genes. This approach also uncovered a "mixed" molecular signature specific to AML early progenitors and characterized by the simultaneous expression of genes associated with both stemness and myeloid priming as well as altered transcriptional programs with an increased expression of proliferation-, self-renewal-, stress response-, and redox signaling-related genes [16].

The increased survival, self-renewal, and expansion capacity of LSC, as compared to HSC, have been shown to be at least in part due to the constitutive activation of NF$\mathrm{KB}$, JAK-STAT, PI3K/AKT/mTOR pathways, to the deletion of tumor suppressor genes (e.g., PTEN), to the upregulation of anti-apoptotic genes, and to alterations in Wnt/ $\beta$ catenin, Hedgehog, and Notch signalings and in microRNA levels (e.g., miR-9 and miR-126) reported in LSC $[9,29]$.

Metabolically, although LSC and HSC are both marked by small amounts of reactive oxygen species (ROS) [30], LSC display distinctive features, including their higher dependence on oxidative phosphorylation and on regulators of mitochondrial functionality, redox balance, and response to stress (e.g., mitophagy-associated proteins including FIS1, the pro-survival protein BCL-2, a cancer-specific heat shock protein species teHsp90, unfolded protein response and, the above mentioned, NF-KB pathway) for their preservation $[5,30]$. Moreover, LSC preferential addiction to amino acid metabolism and enhanced sensitivity to variations in amino acid availability have also been reported [31,32].

Altogether the characterization of dysregulated pathways in LSC has improved since their discovery, the lack of exclusive targetable antigens still limits the development of safe and effective clinical protocols directed against LSC. The application of single-cell technologies to the identification of novel targets in LSC promises to revolutionize the development of targeted therapies.

\subsection{Sources of Heterogeneity in AML-LSC}

AML is a molecularly heterogeneous group of diseases with a complex mutational landscape. Recently, over 5000 driver mutations across 76 genes or genomic regions were identified, with 2 or more drivers present in $86 \%$ of reported cases [33]. AML heterogenous nature is complicated by its clonal structure, with multiple genetically distinct clones co-existing in the same patient $[17,34,35]$.

LSC reflect this clonal architecture and are organized into genetically diverse coexisting subclones $[17,36,37]$ that are in constant evolution throughout the disease progression [36].

The initial attempts to universally define the LSC phenotype as Lin-CD34+CD38- [6,24] were underestimating their phenotypic heterogeneity, potentially due, in part, to antibodyrelated technical artefacts [38].

Although LSC have been shown to be highly enriched within the Lin-CD34+CD38compartment [7] and the abundance of such a compartment has been directly linked to patient outcome, survival, relapse, and minimal residual disease $[39,40]$, recent studies 
revealed that LSC immunophenotypic patterns can change between clones within the same tumor and between AML subtypes.

Indeed, functionally defined LSC have been also detected within the CD34+CD38+, CD34-CD38+, and CD34-CD38- cellular fractions of AML samples. The proportions of LSC within each fraction are highly variable between patients, and LSC of different phenotypic classes are observed in the same sample for the majority of patients [7].

The notion of LSC intra-tumor multivarious immunophenotype is further supported by a recent study revealing the co-existence of at least two LSC fractions with distinct immunophenotypic and molecular signatures in more than $80 \%$ of AML samples analyzed. It was shown that one LSC fraction resembled the lymphoid-primed multipotential progenitors (LMPP) (LMPP-like LSC, Lin-CD34+CD38-CD90-CD45RA+) and the other resided within the granulocyte-macrophage progenitor compartment (GMP) (GMP-like LSC, Lin-CD34+CD38+CD123+CD45RA+). These two LSC populations shared a hierarchical relation, with LMPP-like LSC being upstream of GMP-like LSC. Consistently, LMPP-like LSC had higher frequencies of leukemia-initiating cells and a gene expression profile more similar to immature AML subtypes as compared to GMP-like LSC [41].

This discovery further fuels the existing debate related to the LSC cell of origin being attributed to HSC or committed progenitors [6,8,37,41].

Technological advances in mass cytometry provide a superior tool over flow cytometry to investigate phenotypic variations and intracellular signaling modifications occurring in LSC [42]. Using this technique, Behbehani et al. observed that the expression of several surface markers (e.g., CD7, CD33, CD34, CD38, CD45, CD47, CD71, CD99, CD117, CD123, CD321, HLA-DR) on Lin-CD34+CD38lo LSC varied according to AML genetic signature and karyotype and that different AML subtypes were associated with distinct intracellular signaling in LSC [43]. The association between phenotype and genotype in AML is further supported by other studies $[17,44]$ reinforcing the hypothesis of a fundamental role of mutations in antigenic expression instability throughout clonal selection [17] and the prognostic potential of LSC phenotyping [44].

From a functional point of view, LSC heterogeneity is observed with regard to their self-renewal and in vivo repopulation abilities (with short-term, long-term, and quiescent long-term LSC) [8], and their quiescent state [5]. This latter can be related to the AML genetic background as a recent study showed that the proportion of proliferating LSC increased within AML samples with core-binding factor $(C B F)$ mutations and sensitive to chemotherapy as opposed to poor prognosis samples carrying FLT3-ITD mutation and normal karyotype. These results support the hypothesis that LSC are crucial determinants of clinical outcome [43].

Importantly, LSC plasticity increases upon relapse, as a potential consequence of ineffective treatments [42].

Upon disease relapse in AML, LSC considerably increase in number (9-90-fold) and exhibit higher phenotypic variability [42] and metabolic flexibility, with higher fatty acid metabolism under amino acid shortage [31], as compared to diagnostic specimens. LSC changes upon treatment seem to be only in minor proportion linked to the acquisition of additional genetic aberrations after therapy [42]. Conversely, AML relapse seems to be associated with the selection of pre-existing drug-resistant clones rather than chemotherapyinduced mutations [36].

At least two different AML cell subsets, already present at diagnosis, have been shown to contribute to relapse: early progenitors (LSC) or more committed subsets that have acquired stemness properties. Of relevance, the cell subset giving rise to the recurrence of the disease has been linked to different AML French-American-British subtypes and could further influence the choice of treatment to adopt [36].

In conclusion, as LSC are "moving targets", future targeted therapeutic approaches against AML are likely to shift from a universal to increasingly personalized medicine and may vary according to the stage of the disease to treat. 
Future approaches designed to achieve the targeted eradication of LSC early after diagnosis may prevent their evolution into more complex targets upon treatment [5].

\subsection{The Role of the $B M$ Niche in $A M L$}

In physiological conditions, the BM niche is a composite organization of stromal and hematopoietic cells (including osteoblasts (OB), adipocytes, perivascular mesenchymal stem, endothelial and nervous cells, megakaryocytes, regulatory T-cells (Tregs), and phagocytes) that physically supports HSC and finely controls their self-renewal, proliferation, differentiation, and migratory activities, as extensively reviewed in [45].

In leukemia, neoplastic cells compete with healthy HSC for the BM niche occupancy, by remodeling the environment at their own advantage and creating a hostile habitat for normal hematopoietic stem and progenitor cells (HSPC) [46].

The modifications observed in the BM of AML patients at diagnosis include increased microvessel density [47], neuropathy [48], reduced frequency of CD146+CD166- mesenchymal progenitors [49], decreased OB pool size [50], and diminished adipocyte counts and size [51]. The appearance of these changes observed in the BM niche follows a specific temporal order, reflecting the AML developmental phase. The establishment of a pre-leukemic niche is followed by the development of a leukemia-permissive and lately self-reinforcing environment [52]. Some of these alterations, such as the microvessel density, the loss of nestin expression (indicator of nerve damage), and the aberrant cellular composition of the BM mesenchymal and osteoblastic compartments, have been correlated to AML clinical features, such as aggressiveness, sensitivity to treatment, and patients' overall survival [47-49].

Transgenic mouse models allowing the induction of genetic mutations in distinct BM stromal cell types have revealed that alterations of the BM microenvironment are not only a result but also a potential driver of malignant transformation in HSPC, as reviewed in [53]. The role of the BM microenvironment in the pathogenesis of blood cancers is still subject to debate, although it is considered highly unlikely that it constitutes the first hit of malignant transformation [53].

Conversely, leukemia-induced functional alterations have been reported in several BM niche cellular components (including $\mathrm{OB}$, nerves, adipocytes, and mesenchymal stromal cells (MSC)) in AML mouse models, recapitulating human AML-BM features. Specifically, AML cells can cause OB reduction and malfunctioning $[50,54]$ and sympathetic neuropathy [55] in vivo, all prerequisites for leukemic spread [50,55]. Moreover, leukemic cells carry the potential to hinder the adipogenic differentiation of MSC, resulting in loss of adipocytes in the hematopoietically active red BM [51]. In a recent study using single-cell RNA sequencing (scRNA-seq), Baryawno et al. were able to finely dissect the cellular composition of the BM niche in an AML mouse model and capture the cellular and molecular trajectories taking place in the BM in the initial phase of AML development. In particular, they observed alterations in the osteogenic and adipogenic potential of MSC, arrest in OB maturation, blood vessel remodeling, increased expression of hypoxia-related genes, and decreased expression of HSC-supportive signaling factors [56], in line with the hypothesis of the remodeling of an increasingly leukemia permissive and supportive BM niche.

AML cell intrinsic properties can also profoundly alter the tumor immune microenvironment, hampering the existing anti-tumor response. AML can contribute to defective $\mathrm{T}$ - and natural killer (NK)-cells, by reducing the numbers of $\mathrm{T}$, $\mathrm{T}$ helper (Th) 1 , and cytotoxic T lymphocytes in favor of Tregs and Th17, and by promoting M2-like monocyte polarization $[16,57,58]$. The aberrant immune landscape observed in AML patients is induced by the secretion of immunosuppressive cytokines (e.g., interleukin (IL)- 4 and -10 and transforming growth factor (TGF)- $\beta$ ) and the block of pro-inflammatory ones. T-cell inhibitory enzymes such as indoleamine 2,3-dioxygenase 1 (IDO1) and arginase, of immune checkpoints (e.g., cytotoxic T-lymphocyte antigen-4 (CTLA-4) and programmed death ligand-1 (PD-L1)) and the production of nitric oxide, galectins, and ROS have also been shown to promote an immunosuppressive microenvironment in AML $[52,57,58]$. Recently, 
using an integrated single-cell analysis Van Galen et al. showed that CD14+ monocyte-like AML cells are responsible for mediating immunomodulatory activities [16]. Additionally, the increment of myeloid-derived suppressor cells (MDSC) induced by AML cells enhances the immunosuppression in AML niche [53]. Furthermore, AML cells can preferentially evade immune surveillance by downregulating the expression of major histocompatibility complexes (MHC) and natural killer group 2 member D (NKG2D) ligands, which are required for immune recognition by T- and NK-cells, respectively [59-61].

Majeti et al. observed that LSC and HSC exhibit a divergent expression of pathways related to their crosstalk with the BM niche [28]. Specifically, LSC are unresponsive to Notch and TGF- $\beta$ niche signaling, reported to hinder HSC growth and myeloid differentiation [62], and downregulate CXCR4-STAT3/5B signaling pathways, N-cadherin, and alpha E-catenin [28]. On the contrary, AML cells upregulate CXCR4, VLA-4, CD44, E-selectin, and CD98 adhesion molecules [45,52], and LSC rely on CXCL12/CXCR4 and integrin/OPN signaling for their adhesion and persistence, on Wnt/ $\beta$-catenin and PI3K/Akt signalings for their self-renewal and maintenance [63], and on $\operatorname{SIRP} \alpha / C D 47$ binding for their survival and functionality [64].

The expression of some adhesion factors (e.g., CXCR4, VLA-4, CD44v6 the most common AML CD44 isoform, G protein-coupled receptor 56 (GPR56), and junctional adhesion molecule (JAM)-C) in AML cells/LSC was associated with poor patient survival and was found increased in specific risk groups (e.g., VLA-4 in non-high-risk pediatric and adult patients, and GPR56 at mRNA level in intermediate- and high-risk patients) [65].

Cell-to-cell communication between AML and their BM microenvironment not only occurs through direct contact and exchange of soluble factors but also through exosomes [66].

The AML-BM microenvironment can also support leukemia development by providing energetic supplies and acting as a chemoprotective milieu. For instance, in response to AML stimuli, endothelial cells and adipocytes support leukemic growth and persistence by secreting granulocyte-macrophage colony-stimulating factor (GM-CSF), granulocyte colony-stimulating factor (G-CSF), IL-6, and serving as a source of fatty acids [47,67]. OB can augment neoplastic cell proliferation, through an AML-OB crosstalk involving IL-1 $\beta$ and GM-CSF or by inducing leukemic cells to secrete higher levels of IL-8, a pro-angiogenic factor [68].

BM-mediated chemoprotection can be promoted by several cell types, including cancer-associated fibroblasts (CAF), -through the release of growth differentiation factor 15 [69], activator of TGF- $\beta$ signaling in chemo-resistant leukemic cells [70]-, and endothelial cells, through the production of vascular endothelial growth factor (VEGF) and other adhesion molecules which trigger survival and proliferative pathways in AML cells [47]. MSC can contribute to AML survival, for example, by inducing the activation of Notch [71] and c-Myc [72] signaling and increasing the expression of anti-apoptotic factors Bcl-2 and $\mathrm{Bcl}-\mathrm{X}_{\mathrm{L}}$ [73]. MSC have also been described to act as a source of functional mitochondria for leukemic cells and LSC, thus fueling their energetic consumption [74].

The hypoxic nature of AML-BM microenvironment can also contribute to AML chemoresistance by favoring quiescence of leukemic cells [75]. This is due to hypoxiainduced cell cycle arrest and pro-survival signaling, as indicated by the upregulation of p27 (a regulator of cell cycle which prevents S-phase entrance), the increased expression of XIAP (an anti-apoptotic molecule), and the pro-survival PI3K/AKT pathway activation observed in AML cells upon in vitro culture in hypoxic conditions [76].

A more extensive summary of BM-chemoprotection mechanisms is reviewed in [11].

BM immunohistopathology of leukemia xenograft models localized residual leukemic cells, after chemotherapeutic treatment, in proximity to the vascular endothelium and to the endosteum, supporting the role of the BM niche in preserving LSC from the effect of chemotherapeutic agents [10].

Overall, these peculiar features of the AML niche are likely to impact on drug efficacy and their function should be taken into account when testing novel therapies. 
2/3D in vitro co-culture systems and 3D in vivo ectopic BM ossicles, which better recapitulate the complexity of the human pathologic $\mathrm{BM}$, are becoming critical tools to test drug efficacy in a human-resembling environment, as reported in [77], and to identify potential new therapeutic targets involved in leukemia-stromal interactions. An exemplification of the broad applicability of in vitro BM niche models in the leukemic context was recently provided by a sophisticated leukemia-on-a-chip technology [78]. This was applied to the investigation of the B-cell acute lymphoblastic leukemia (B-ALL) microenvironment but carries great potential in AML.

Moreover, single-cell technologies are emerging as a powerful tool to dissect normal and, more importantly, pathological niches. They are allowing to understand how leukemia reshapes the BM microenvironment for the identification of cellular and molecular alterations potentially predictive of patient survival and/or targetable with specific stromal/immune microenvironment-directed therapeutic approaches $[19,56]$.

Novel strategies investigating the preclinical/clinical utility of exploiting and targeting peculiar features of the AML niche (as hypoxia, adhesion molecules, cellular, and immune aberrations) to treat the disease are currently under investigation $[22,52,53,65]$. $\mathrm{BM}$ therapeutic targeting could not only hinder AML progression but also sustain and preserve normal hematopoiesis [51].

\section{CAR T-Cells and Their Current Clinical Application in AML Therapy}

Chimeric antigen receptor (CAR) T-cell therapy is a form of "adoptive T-cell transfer", originally described in the late 1980s by Eshhar et al. [79-81]. The CAR is an artificial receptor, integrating an extracellular antigen-binding domain comprised of the variable region (variable heavy [VH] domain-linker-variable light [VL] domain) and the hinge region of an antibody fused to a transmembrane domain. The transmembrane domain is connected to cytoplasmic signal transducing chains, such as the TCR- $\zeta(\mathrm{CD} 3 \zeta)$ and the costimulatory domains (e.g., CD28, 4-1BB, ICOS, OX40), which promote T-cell activation [82]. When the CAR is expressed on the T-cell surface (CAR T-cell), it mediates a non-MHCrestricted antigen recognition coupled to T-cell activation, a property scientists exploit to target tumor antigens and eradicate cancer. In a clinical setting, patients could receive CAR T-cells derived from their own T-lymphocytes engineered ex vivo (autologous CAR T therapy) [83] or from a donor's T-cells (allogeneic CAR T therapy) [84].

Autologous CAR T-cell therapy demonstrated promising results in a series of clinical trials against chronic lymphocytic leukemia [85-87], B-ALL [87-92], and diffuse large B-cell lymphoma [92-99], leading to the Food and Drug Administration (FDA) and European Medicines Agency (EMA) approval of two autologous anti-CD19 CAR T drugs, namely Kymriah $^{\mathrm{TM}}[100-102]$ and Yescarta ${ }^{\mathrm{TM}}[103,104]$.

In the AML context, CAR T-cell application is at its dawn, with a limited number of reported clinical trials and benefits in the treated patients. The first clinical application of CAR T-cells had been reported in 2013 by Ritchie et al. targeting Lewis-Y antigen with unsatisfactory results [105]. Since then, reported AML CAR T clinical trials targeted mainly one single antigen (mostly CD33, CD123, and NKG2D ligands) [106]. Up to 2021, across all AML reported clinical trials, an estimate of 65 AML patients have been treated with CAR T products, only a quarter of whom have achieved complete remission [106]. As summarized in [106], most of the anti-CD33 CAR T-cell therapies resulted in partial responses, and no responses were observed in all 31 patients treated with anti-NKG2D ligands CAR T-cells across three studies. The most encouraging results have been reported by 3 patients who reached complete remission within one month after being infused with anti-CLL1 CAR T-cells [107].

To date, there are more than 20 ongoing AML CAR T clinical trials registered with the clinicaltrials.gov. This number is expected to grow as more target antigens are evaluated preclinically. Relevant target antigens include: CD135 [108-110], CD38 [111], folate receptor (FR)- $\beta$ [112,113], WT1 [114,115], B7-H3 [116,117], CD70 [118,119], and CD7 [120]. For an overview on the indexed CAR T clinical trials in AML and the CAR constructs they employ, 
we refer the reader to the recent reviews from Mardiana and Gill [121] and Fiorenza and Turtle [106].

In the next paragraph, we discuss the main obstacles impeding CAR T-cell successful application in AML and potential strategies to overcome them.

\section{CAR T-Cell Approaches in AML: Challenges and Novel Strategies}

Although several preclinical and clinical studies are investigating CAR T-cell approaches in AML, their successful application remains challenging [122].

Beside the general limitations of CAR T-cell therapies (e.g., toxicities (cytokine release syndrome and neurotoxicity), relapse, durability of the response, and accessibility to the treatment) [123,124], CAR T exploitation in AML is further challenged by the complex pathobiology of this disease.

The obstacles limiting the application of CAR T-cells to AML include the lack of a universal and tumor-specific antigen, and an immunosuppressive tumor microenvironment, as reported for solid tumors [121,124,125].

In the next sections, we discuss the challenges for CAR T-cell use in AML in light of the disease characteristics: (1) identification of specific LSC/leukemic CAR target, (2) AML heterogeneity, and (3) leukemic BM niche. Limitations and potential rescue strategies are schematized in Figure 2.

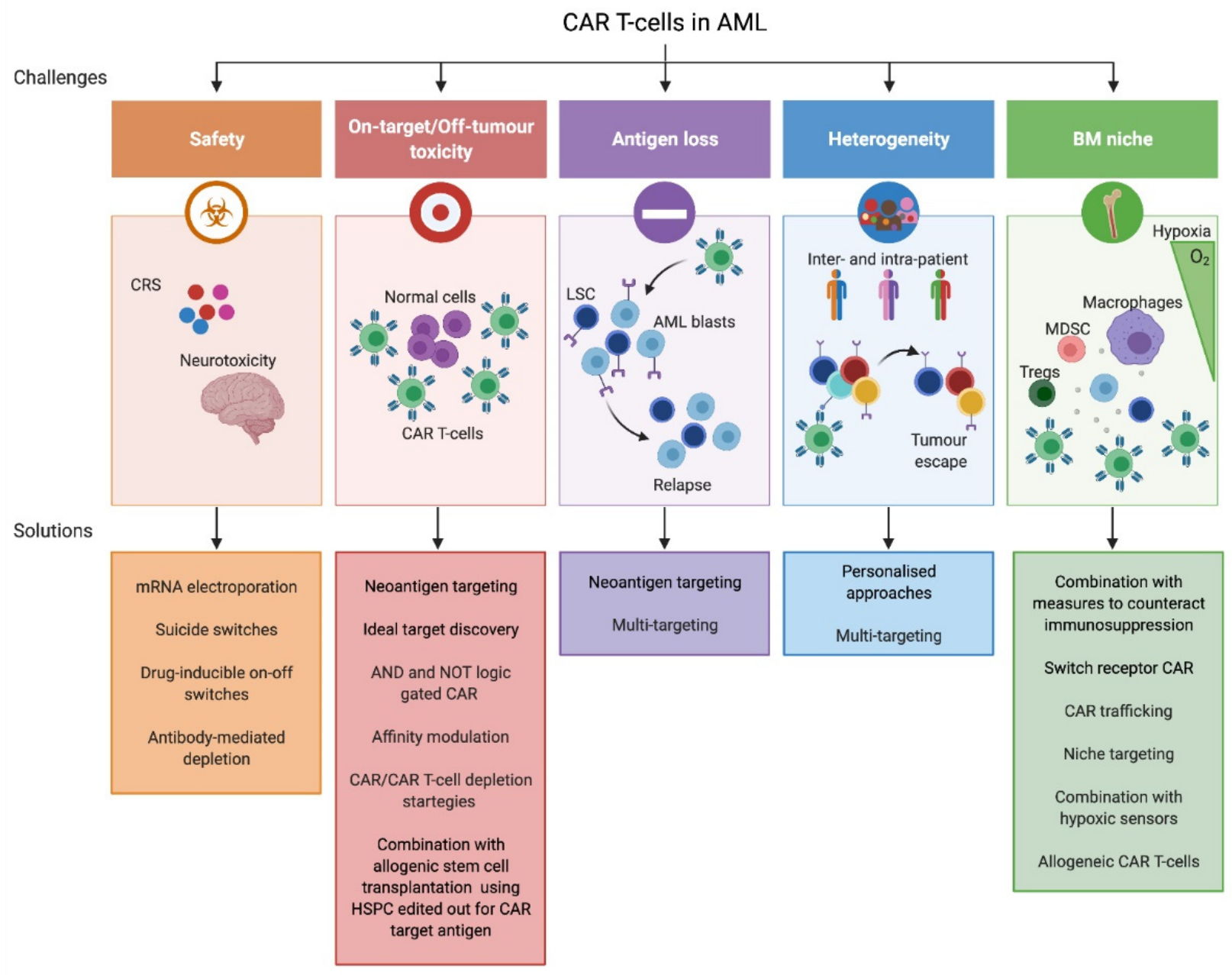

Figure 2. Schematization of chimeric antigen receptor (CAR) T-cell limitations in acute myeloid leukemia (AML) therapy and possible strategies to overcome them. Cytokine release syndrome (CRS) and neurotoxicity are the most frightening side effects related to the use of CAR T-cells in patients. Strategies to deplete CAR/CAR T-cells (e.g., mRNA electroporation of the CAR, suicide switches, drug-inducible on-off switches, and antibody-mediated depletion) could be employed to reduce 
the persistence of the toxicity. Due to the absence of an ideal target in AML, CAR T-cells impact normal cells expressing the target antigen. Thus, it is essential to identify suitable neoantigens and novel potential targets (leukemia-specific). To overcome on-target/off-tumor toxicity, AND- and NOT-logic-gated CAR can be employed to increase specificity. Affinity fine-tuning, CAR/CAR T-cell depletion strategies, and a combination of CAR therapies with allogeneic HSPC transplantation edited out for CAR target are further solutions to be considered. Antigen loss can occur upon CAR treatment. However, the targeting of neoantigens, stably expressed on leukemic cells, or of multiple antigens should overcome it. AML inter- and intra-patient heterogeneity renders extremely difficult a general application of CAR T in all AML patients, suggesting that a personalized approach and combinatorial CAR strategies are required. Lastly, AML-BM niche might affect CAR T-cell functionality due to its hypoxic and immunosuppressive nature. Moreover, it could protect LSC from CAR T-cell effectiveness. Strategies to combat immunosuppression should be considered alongside CAR infusion. Armored or switch receptor CAR can be employed as well. Specific antigen expression or hypoxia can be exploited for CAR trafficking or niche targeting increasing CAR T potency in the cradle of LSC. To overcome potential alterations of AML T-cells that can render them not suitable for CAR T-cell manufacturing, allogeneic T-cells engineered to bypass graft-versus-host disease and rejection and to express CAR can be used. CRS, cytokine release syndrome; CAR, chimeric antigen receptor; LSC, leukemic stem cells; AML, acute myeloid leukemia; HSPC; hematopoietic stem and progenitor cells; BM, bone marrow; MDSC, myeloid-derived suppressor cells; Tregs, regulatory T-cells.

\subsection{CAR T-Cell Antigens in AML and Strategies to Overcome on-Target/Off-Tumour Effects}

The primary barrier to the successful application of CAR in AML is the lack of surface targets that are specifically expressed on AML leukemic cells in the majority of patients, but not on normal tissues [126].

The vast majority of markers investigated so far are not restricted to LSC/leukemic cells but are also found on normal hematopoietic progenitors, on mature cells (e.g., CD7 on T-cells) and on non-hematopoietic sites (e.g., CD33 on Kupffer cells, CD123 on endothelial cells, CD44v6 and CD47 on keratinocytes, FLT3 on neurons and testis, CLL1 on lung and gastrointestinal epithelial cells) [122].

As a consequence, although the CAR T-cells that are being tested for AML exhibit a potent anti-leukemic effect in preclinical studies, the majority of them only show modest effectiveness in clinical trials and are associated with myeloablation, cytopenia, and severe extramedullary effects [106,121,122]. The on-target/off-tumor toxicity effects observed in AML are less tolerable than the B-cell aplasia induced by anti-CD19 CAR T-cell treatment in ALL and they can be lethal upon prolonged exposure [121,122]. Thus, clinical evidence suggests that current CAR T-cell strategies in AML could serve as a bridge to hematopoietic stem cell transplantation rather than a stand-alone therapy $[127,128]$.

Potential strategies to avoid fatal side-effects, due to the lack of leukemia-specific antigens, include (1) discovering novel LSC/leukemic specific antigens, (2) optimizing the design of CAR T-cell treatments, (3) optimizing the design of CAR products, and (4) controlling CAR T-cell activity in vivo.

(1) To broaden the spectrum of targetable antigens, it is possible to redirect CAR Tcells to target intracellular neoepitopes when presented by HLA complex on AML cells, as exemplified by the recently developed CAR against NPM1c epitope-HLA-A2 complex [129]. Additionally, FLT3-ITD is a candidate tumor-specific CAR antigen, as it is endogenously processed by leukemic cells generating an immunogenic mutated peptide [130].

Moreover, alternative splicing-derived AML neoantigens represent (e.g., CD44v6) or may represent (e.g., FLT3-Va and NOTCH2-Va) immunotherapeutic targets [131], with CD44v6 CAR T-cells exhibiting anti-cancer killing preclinically [132] and being currently investigated in clinic (NCT04097301).

Notably, it is essential to select neoantigens expressed on the vast majority of, if not all, AML cells and patients to obtain a large applicability.

Moreover, it is unlikely that neoantigens undergo antigen loss and therefore they serve as optimal immunotherapeutic targets [131].

Epitope-HLA complex targeting may be extended to intracellular proteins selectively expressed by AML blasts/LSC, as TARP identified through differential gene expression screening [133]. 
As previously mentioned, scRNA-seq can be applied to the identification of novel targets to be subsequently validated at the protein level. Furthermore, the recently developed sequentially tumor-selected antibody and antigen retrieval (STAR) system has been applied to screen and identify nanobodies preferentially binding to AML cells, potentially informing leukemia-specific CAR T-cell strategies [134].

(2) It has been recently shown that CAR T-cell infusion combined with the transplantation of HSPC, in which the CAR-targeted antigen (e.g., CD33) is edited out prior to CAR infusion, can be successfully applied to avoid off-tumor toxicity. This strategy can be extended to other antigens and, after appropriate considerations, translated into patients [135].

(3) On-target/off-tumor CAR T-cell side effects can be overcome by logic-gated CAR T-cells, which require the targeting of multiple antigens in order to exert their cytotoxic effect. Specifically, "AND-gated" dual CAR T-cells can only activate when at least two markers are expressed on the target cells. Conversely, "NOT-gated" CAR T-cells require the expression of one marker and the absence of a second one to exert anti-tumor effects [124]. However, high-throughput integrated transcriptome and surface proteome analyses in AML blasts / LSC failed to identify suitable antigen combinations for the design of dual CAR strategies, due to the high heterogeneity observed in this leukemia [126]. Another study has identified CD33-TIM3 and CLL1-TIM3 as potential combinations for the development of dual CAR approaches and will require further validation [136]. Dual CD13-TIM3 CAR T-cells evaluated in preclinical settings exhibited anti-leukemic potential with limited HSC toxicity [134].

The affinity of CAR to their cognate antigens can influence on-target/off-tumor effects. The effect of CAR affinity on CAR T-cell functionality has generated controversial results [82], probably due to the antigen-dependent variability and the CAR construct utilized. Low-affinity CAR can better discriminate cells with different antigen expression levels, leading to the preferential targeting of malignant cells (overexpressing tumor antigen) over normal cells (expressing the antigen at physiological levels) [82]. Thus, their use would be ideally placed in AML, to minimize the off-leukemia drawbacks. Low-affinity CD123 CAR exhibit similar anti-leukemic properties to wild-type and high-affinity ones but a promising safer profile in vitro, as determined by reduced cytotoxicity against lowly antigen-positive cells [137]. On the other hand, while decreasing the affinity of CAR T-cells against FR- $\beta$ in AML can prevent their off-tumor toxicity in monocytes, it does not provide sufficient anti-leukemic activity [113]. Further investigations will be necessary to fine-tune CAR affinities to balance anti-tumor potency and toxicity.

(4) Finally, CAR mRNA electroporation in T-cells, suicide switches, drug-inducible on-off switches, or antibody-mediated CAR T elimination are strategies to control CAR T-cell lifespan and limit their side effects [23,124,132,138-140]. However, their translation in clinic needs accurate evaluation [141].

\subsection{AML Phenotypic Heterogeneity Challenges the Identification of Target Antigens for AML CAR T-Cell Strategies}

The inter- and intra-patient genetic and phenotypic heterogeneity of AML limits the design of a universal CAR T-cell strategy.

As a result, the selection of candidate surface antigens requires a more personalized approach varying according to the age of the patient [142], disease phenotype [143], and stage $[42,136]$. In a recent study, a stable expression at diagnosis and relapse for CD33, CD123, TIM3, and CD7 has been reported [136]. Further studies investigating the stability of cell surface markers in LSC / AML blasts throughout the progression of AML are needed, especially at relapse, when CAR T-cell therapies are more likely to be utilized.

The mutational landscape can also contribute to AML immunophenotypic patterns [43]. For instance, CD123 [144] and CD26 [44] display high expression in FLT3-ITD-mutated LSC, NPM1c-HLA-A2 complex in NPM1c+HLA-A2+ AML [129], and CD33-FLT3 in KMT2A-mutated infant patients [142]. 
Antigen loss or reduced expression on the tumor cell surface is one of the main causes of disease relapse in CD19 CAR T-cell therapy [123]. Similarly, in AML, CAR T-cells against antigens with heterogeneous expression are likely to result in relapse due to incomplete targeting and clonal selection, especially if single antigens are targeted [127].

Overcoming this limitation is likely to require the targeting of multiple antigens (CAR/CAR strategy) [139]. Indeed, CAR T-cells concurrently targeting antigens on LSC and AML blasts (CD123, CD33) have shown remarkable preclinical results [139]. Perna et al. and Haubner et al. used transcriptomics, surface proteomics, and flow cytometry to systematically identify targets expressed in primary AML-LSC but absent in HSPC and healthy tissues $[126,136]$. By doing so, they identified candidate antigen combinations for CAR/CAR strategies (e.g., ADGRE2-CD33, CCR1-CLEC12A, CD70-CD33, LILRB2CLEC12A [126], CLL1-TIM3 [136]), which will require functional validation. Dual CAR targeting (involving CD123, CD33, CLL1) is also being tested in clinical trials (NCT03795779, NCT04156256, NCT04010877). Encouraging results have been reported for CLL1-CD33 CAR T-cell treatment (NCT03795779) [145].

Moving toward a personalized medicine approach, recent clinical studies are investigating patient-tailored approaches combining CAR T-cells against various targets according to patient's AML phenotypes (NCT03222674, NCT03473457).

\subsection{Targeting the AML Tumour Microenvironment with CAR T-Cells}

So far, there is no direct evidence of the impact of the AML niche on CAR T-cell functions. Given its immunosuppressive and hypoxic nature, it is likely that the AMLBM niche may hamper CAR T-cell functionality. Thus, CAR T-cell strategies targeting both leukemia cells and their microenvironment may represent a double-edged approach, counteracting the pro-leukemic BM microenvironment on one side and directing CAR T-cells to the LSC-enriched BM on the other.

The microenvironment-mediated impairment of CAR T-cell functions is well documented in solid tumors and B-cell malignancies, where it can be mediated by various cell types, including MDSC, macrophages, and Tregs. A similar mechanism may be extended to AML $[125,146]$.

Despite the immunomodulatory functions of BM-MSC and their role in tumor evolution [147], few studies have investigated their effect on CAR T-cell functions and generated conflicting results, showing negative [148], positive [149], or lack of [132,150] impact. In solid tumors, CAF block T-cell infiltration [125] and contribute to immunosuppression and immunotherapy resistance [151] while supporting cancer growth [125]. These observations have led to several preclinical studies testing CAR T-cells against the fibroblast activation protein (FAP) expressed in CAF. These studies have shown encouraging anti-tumor effects but, in some cases, have also displayed severe toxicities due to the expression of FAP on healthy tissues, as summarized in [125]. To date, only one study has evaluated the role of the BM-MSC in CAR T-cell resistance in AML context [132] and further investigation is required.

To counteract the tumor-associated immunosuppressive environment, fourth-generation "armored" CAR have been engineered to produce immune-stimulatory cytokines (e.g., IL12) [124], to release PD-1-blocking single chain variable fragments [152], or to constitutively express CD40L in order to raise endogenous anti-cancer immune response [153]. Chimeric constructs, coupling the extracellular domain of an inhibitory T-cell receptor (e.g., PD-1) with intracellular costimulatory signal, have also been described in CAR T-cells [154].

Additional strategies to counteract the tumor immunosuppressive microenvironment in the CAR T-cell context are described elsewhere $[125,146]$.

Trafficking receptors (e.g., CXCR4) [155] may be useful to preferentially direct CAR T-cells to the BM, potentially boosting the eradication of residual LSC. Alternatively, the combination of CAR T-cells with LSC mobilizers might favor the egress of LSC from their niche [65] and their consequent killing by CAR T-cells in a non-hostile environment for CAR T-cells. 
It is still to be determined whether the hypoxic nature of the AML niche positively or negatively influences CAR T-cell functions. Hypoxic environments have been shown to promote central memory phenotype in CAR T-cells, which is beneficial for their functionality [156], but on the other hand reduce CAR T proliferation and hinder their effector memory differentiation and functionality (the latter being due to Tregs recruitment and enhancement of PD-L1 expression) [125]. Moreover, the hypoxic environment can alter the surface phenotype of AML cells in vitro [157], suggesting that the effect of hypoxia should be evaluated when selecting CAR T-cell targets to avoid antigen escape. A recent study illustrates how hypoxia-sensitive CAR T-cells, able to specifically activate in hypoxic sites (such as the AML-BM microenvironment) can be employed to avoid unwanted off-site toxicities [158]. This approach could be investigated to eradicate residual LSC persisting in the hypoxic BM niche after chemotherapy.

The application of in vitro and in vivo humanized BM niche models will be crucial to understand how the AML-BM modulates CAR T-cell functions and to identify therapeutic targets in the pathological niche.

Finally, AML intrinsic features and prior chemotherapy treatments may impact on the fitness of the underlying T-cell populations used for CAR engineering, challenging the successful manufacture of autologous CAR T-cells from AML patients [121]. Allogeneic CAR T-cells engineered to attenuate graft-versus-host disease and rejection may be employed to achieve faster and broader product availability [159]. A phase I clinical study is currently investigating the applicability of universal CD123 CAR T-cells in AML (NCT03190278).

\section{Conclusions}

The complexity of AML biology has led to unsatisfactory clinical outcomes so far. The quiescent and immune-evasive nature of LSC makes them critical players in therapy escape and disease relapse, suggesting that their effective targeting is imperative for curative treatments. In this context, CAR T-cells represent a promising option, as they can effectively target tumor cells irrespectively of their quiescent status or their immune visibility, by mediating MHC-independent tumor recognition and targeting.

In this review, we summarized the main characteristics of AML-LSC and the AML$\mathrm{BM}$ niche in the context of their therapeutic targeting using CAR T-cells. Moreover, we highlighted several potential strategies to minimize toxicity while preserving or increasing CAR T-cell functions.

Although CAR T-cells have been successfully applied for the treatment of several hematological malignancies and their translation to AML is in its infancy, it is clear that the pathobiology of the disease represents the main barrier to their successful exploitation. Specifically, the lack of LSC/AML-specific target antigens, the heterogeneity of the disease and the potential role of the AML pathologic BM microenvironment stand out as some of the main obstacles. Additionally, AML patients' age and their general compromised health status increase the risks of CAR T-cell related toxicities.

It is increasingly clear that the application of CAR T-cells to AML will require personalized and multi-targeted approaches and these strategies are currently investigated in clinical trials.

Luckily, the CAR T-cell research field is continuously evolving and there is still room for improvement. In particular, recent single-cell technologies can be applied to identify novel candidate antigen combinations in AML cells and their niche. The advances in CAR engineering and the introduction of control switches will lead to increased CAR activity and specificity and reduced toxicity.

Open questions remain: (1) Is there a broadly applicable antigen combination across AML subtypes? (2) Are some of the emerging strategies (e.g., CAR depletion, nichetargeting) feasible in a clinical setting? (3) Could CAR T-cells ever be used as a stand-alone therapy in AML? (4) Can stratification systems be developed to identify patients eligible for CAR T-cells as a first-line treatment? 
Author Contributions: I.M.M. conceptualized and wrote the paper and prepared the figures; E.K. contributed to writing the manuscript; A.G. critically revised the work. All authors have read and agreed to the published version of the manuscript.

Funding: Part of this work was funded by the NIHR HS\&DR Programme (14/21/45) and supported by the NIHR GOSH BRC. The views expressed are those of the author(s) and not necessarily those of the NHS, the NIHR, or the Department of Health. A.G.'s lab is supported by the Leukaemia UK John Goldman Fellowship (2018/JGF/003), the Rosetrees Trust fund (M700), the Academy of Medical Sciences Springboard Award (SBF004\1025), and Cancer Research UK (C65772/A29812).

Acknowledgments: The authors thank Sergi Castellano for helpful discussion. The figures in this review were created with BioRender.com (accessed on 4 May 2021).

Conflicts of Interest: The authors declare no conflict of interest.

\section{References}

1. De Kouchkovsky, I.; Abdul-Hay, M. Acute myeloid leukemia: A comprehensive review and 2016 update. Blood Cancer J. 2016, 6, e441. [CrossRef]

2. American Cancer Society. Key Statistics for Acute Myeloid Leukemia (AML). Available online: https://www.cancer.org/cancer/ acute-myeloid-leukemia/about/key-statistics.html (accessed on 9 May 2021).

3. Dohner, H.; Estey, E.; Grimwade, D.; Amadori, S.; Appelbaum, F.R.; Buchner, T.; Dombret, H.; Ebert, B.L.; Fenaux, P.; Larson, R.A.; et al. Diagnosis and management of AML in adults: 2017 ELN recommendations from an international expert panel. Blood 2017, 129, 424-447. [CrossRef] [PubMed]

4. Oliva, E.N.; Franek, J.; Patel, D.; Zaidi, O.; Nehme, S.A.; Almeida, A.M. The Real-World Incidence of Relapse in Acute Myeloid Leukemia (AML): A Systematic Literature Review (SLR). Blood 2018, 132, 5188. [CrossRef]

5. Pollyea, D.A.; Jordan, C.T. Therapeutic targeting of acute myeloid leukemia stem cells. Blood 2017, 129, 1627-1635. [CrossRef]

6. Bonnet, D.; Dick, J.E. Human acute myeloid leukemia is organized as a hierarchy that originates from a primitive hematopoietic cell. Nat. Med. 1997, 3, 730-737. [CrossRef]

7. $\quad$ Eppert, K.; Takenaka, K.; Lechman, E.R.; Waldron, L.; Nilsson, B.; van Galen, P.; Metzeler, K.H.; Poeppl, A.; Ling, V.; Beyene, J.; et al. Stem cell gene expression programs influence clinical outcome in human leukemia. Nat. Med. 2011, 17, 1086-1093. [CrossRef] [PubMed]

8. Hope, K.J.; Jin, L.; Dick, J.E. Acute myeloid leukemia originates from a hierarchy of leukemic stem cell classes that differ in self-renewal capacity. Nat. Immunol. 2004, 5, 738-743. [CrossRef] [PubMed]

9. Siveen, K.S.; Uddin, S.; Mohammad, R.M. Targeting acute myeloid leukemia stem cell signaling by natural products. Mol. Cancer 2017, 16, 13. [CrossRef]

10. Ninomiya, M.; Abe, A.; Katsumi, A.; Xu, J.; Ito, M.; Arai, F.; Suda, T.; Ito, M.; Kiyoi, H.; Kinoshita, T.; et al. Homing, proliferation and survival sites of human leukemia cells in vivo in immunodeficient mice. Leukemia 2007, 21, 136-142. [CrossRef]

11. Korn, C.; Mendez-Ferrer, S. Myeloid malignancies and the microenvironment. Blood 2017, 129, 811-822. [CrossRef]

12. Miles, L.A.; Bowman, R.L.; Merlinsky, T.R.; Csete, I.S.; Ooi, A.T.; Durruthy-Durruthy, R.; Bowman, M.; Famulare, C.; Patel, M.A.; Mendez, P.; et al. Single-cell mutation analysis of clonal evolution in myeloid malignancies. Nature 2020, 587, 477-482. [CrossRef]

13. Potter, N.; Miraki-Moud, F.; Ermini, L.; Titley, I.; Vijayaraghavan, G.; Papaemmanuil, E.; Campbell, P.; Gribben, J.; Taussig, D.; Greaves, M. Single cell analysis of clonal architecture in acute myeloid leukaemia. Leukemia 2019, 33, 1113-1123. [CrossRef] [PubMed]

14. Nam, A.S.; Kim, K.T.; Chaligne, R.; Izzo, F.; Ang, C.; Taylor, J.; Myers, R.M.; Abu-Zeinah, G.; Brand, R.; Omans, N.D.; et al. Somatic mutations and cell identity linked by Genotyping of Transcriptomes. Nature 2019, 571, 355-360. [CrossRef]

15. Rodriguez-Meira, A.; Buck, G.; Clark, S.A.; Povinelli, B.J.; Alcolea, V.; Louka, E.; McGowan, S.; Hamblin, A.; Sousos, N.; Barkas, N.; et al. Unravelling Intratumoral Heterogeneity through High-Sensitivity Single-Cell Mutational Analysis and Parallel RNA Sequencing. Mol. Cell 2019, 73, 1292-1305. [CrossRef] [PubMed]

16. Van Galen, P.; Hovestadt, V.; Wadsworth Ii, M.H.; Hughes, T.K.; Griffin, G.K.; Battaglia, S.; Verga, J.A.; Stephansky, J.; Pastika, T.J.; Lombardi Story, J.; et al. Single-Cell RNA-Seq Reveals AML Hierarchies Relevant to Disease Progression and Immunity. Cell 2019, 176, 1265-1281. [CrossRef] [PubMed]

17. Morita, K.; Wang, F.; Jahn, K.; Hu, T.; Tanaka, T.; Sasaki, Y.; Kuipers, J.; Loghavi, S.; Wang, S.A.; Yan, Y.; et al. Clonal evolution of acute myeloid leukemia revealed by high-throughput single-cell genomics. Nat. Commun. 2020, 11, 5327. [CrossRef] [PubMed]

18. Giustacchini, A.; Thongjuea, S.; Barkas, N.; Woll, P.S.; Povinelli, B.J.; Booth, C.A.G.; Sopp, P.; Norfo, R.; Rodriguez-Meira, A.; Ashley, N.; et al. Single-cell transcriptomics uncovers distinct molecular signatures of stem cells in chronic myeloid leukemia. Nat. Med. 2017, 23, 692-702. [CrossRef] [PubMed]

19. Witkowski, M.T.; Dolgalev, I.; Evensen, N.A.; Ma, C.; Chambers, T.; Roberts, K.G.; Sreeram, S.; Dai, Y.; Tikhonova, A.N.; Lasry, A.; et al. Extensive Remodeling of the Immune Microenvironment in B Cell Acute Lymphoblastic Leukemia. Cancer Cell 2020, 37, 867-882. [CrossRef] 
20. Stahl, M.; Lu, B.Y.; Kim, T.K.; Zeidan, A.M. Novel Therapies for Acute Myeloid Leukemia: Are We Finally Breaking the Deadlock? Target. Oncol. 2017, 12, 413-447. [CrossRef]

21. Tan, Y.; Wu, Q.; Zhou, F. Targeting acute myeloid leukemia stem cells: Current therapies in development and potential strategies with new dimensions. Crit. Rev. Oncol. Hematol. 2020, 152, 102993. [CrossRef]

22. Karantanou, C.; Godavarthy, P.S.; Krause, D.S. Targeting the bone marrow microenvironment in acute leukemia. Leuk. Lymphoma 2018, 59, 2535-2545. [CrossRef]

23. Miliotou, A.N.; Papadopoulou, L.C. CAR T-cell Therapy: A New Era in Cancer Immunotherapy. Curr. Pharm. Biotechnol. 2018, 19, 5-18. [CrossRef] [PubMed]

24. Lapidot, T.; Sirard, C.; Vormoor, J.; Murdoch, B.; Hoang, T.; Caceres-Cortes, J.; Minden, M.; Paterson, B.; Caligiuri, M.A.; Dick, J.E. A cell initiating human acute myeloid leukaemia after transplantation into SCID mice. Nature 1994, 367, 645-648. [CrossRef]

25. Ishikawa, F.; Yoshida, S.; Saito, Y.; Hijikata, A.; Kitamura, H.; Tanaka, S.; Nakamura, R.; Tanaka, T.; Tomiyama, H.; Saito, N.; et al. Chemotherapy-resistant human AML stem cells home to and engraft within the bone-marrow endosteal region. Nat. Biotechnol. 2007, 25, 1315-1321. [CrossRef] [PubMed]

26. Ho, J.M.; Dobson, S.M.; Voisin, V.; McLeod, J.; Kennedy, J.A.; Mitchell, A.; Jin, L.; Eppert, K.; Bader, G.; Minden, M.D.; et al. CD200 expression marks leukemia stem cells in human AML. Blood Adv. 2020, 4, 5402-5413. [CrossRef]

27. Zhou, J.; Chng, W.J. Identification and targeting leukemia stem cells: The path to the cure for acute myeloid leukemia. World J. Stem Cells 2014, 6, 473-484. [CrossRef] [PubMed]

28. Majeti, R.; Becker, M.W.; Tian, Q.; Lee, T.L.; Yan, X.; Liu, R.; Chiang, J.H.; Hood, L.; Clarke, M.F.; Weissman, I.L. Dysregulated gene expression networks in human acute myelogenous leukemia stem cells. Proc. Natl. Acad. Sci. USA 2009, 106, 3396-3401. [CrossRef]

29. Konopleva, M.; Zhao, S.; Hu, W.; Jiang, S.; Snell, V.; Weidner, D.; Jackson, C.E.; Zhang, X.; Champlin, R.; Estey, E.; et al. The anti-apoptotic genes $\mathrm{Bcl}-\mathrm{X}(\mathrm{L})$ and $\mathrm{Bcl}-2$ are over-expressed and contribute to chemoresistance of non-proliferating leukaemic CD34+ cells. Br. J. Haematol. 2002, 118, 521-534. [CrossRef]

30. Mattes, K.; Vellenga, E.; Schepers, H. Differential redox-regulation and mitochondrial dynamics in normal and leukemic hematopoietic stem cells: A potential window for leukemia therapy. Crit. Rev. Oncol. Hematol. 2019, 144, 102814. [CrossRef] [PubMed]

31. Jones, C.L.; Stevens, B.M.; D’Alessandro, A.; Reisz, J.A.; Culp-Hill, R.; Nemkov, T.; Pei, S.; Khan, N.; Adane, B.; Ye, H.; et al. Inhibition of Amino Acid Metabolism Selectively Targets Human Leukemia Stem Cells. Cancer Cell 2018, 34, 724-740. [CrossRef] [PubMed]

32. Michelozzi, I.M.; Granata, V.; De Ponti, G.; Alberti, G.; Tomasoni, C.; Antolini, L.; Gambacorti-Passerini, C.; Gentner, B.; Dazzi, F.; Biondi, A.; et al. Acute myeloid leukaemia niche regulates response to L-asparaginase. Br. J. Haematol. 2019, 186, 420-430. [CrossRef] [PubMed]

33. Papaemmanuil, E.; Gerstung, M.; Bullinger, L.; Gaidzik, V.I.; Paschka, P.; Roberts, N.D.; Potter, N.E.; Heuser, M.; Thol, F.; Bolli, N.; et al. Genomic Classification and Prognosis in Acute Myeloid Leukemia. N. Engl. J. Med. 2016, 374, 2209-2221. [CrossRef] [PubMed]

34. Cancer Genome Atlas Research, Network; Ley, T.J.; Miller, C.; Ding, L.; Raphael, B.J.; Mungall, A.J.; Robertson, A.; Hoadley, K.; Triche, T.J., Jr.; Laird, P.W.; et al. Genomic and epigenomic landscapes of adult de novo acute myeloid leukemia. N. Engl. J. Med. 2013, 368, 2059-2074. [CrossRef] [PubMed]

35. Klco, J.M.; Spencer, D.H.; Miller, C.A.; Griffith, M.; Lamprecht, T.L.; O’Laughlin, M.; Fronick, C.; Magrini, V.; Demeter, R.T.; Fulton, R.S.; et al. Functional heterogeneity of genetically defined subclones in acute myeloid leukemia. Cancer Cell 2014, 25, 379-392. [CrossRef]

36. Shlush, L.I.; Mitchell, A.; Heisler, L.; Abelson, S.; Ng, S.W.K.; Trotman-Grant, A.; Medeiros, J.J.F.; Rao-Bhatia, A.; JaciwZurakowsky, I.; Marke, R.; et al. Tracing the origins of relapse in acute myeloid leukaemia to stem cells. Nature 2017, 547, 104-108. [CrossRef]

37. Quek, L.; Otto, G.W.; Garnett, C.; Lhermitte, L.; Karamitros, D.; Stoilova, B.; Lau, I.J.; Doondeea, J.; Usukhbayar, B.; Kennedy, A.; et al. Genetically distinct leukemic stem cells in human CD34- acute myeloid leukemia are arrested at a hemopoietic precursor-like stage. J. Exp. Med. 2016, 213, 1513-1535. [CrossRef]

38. Taussig, D.C.; Miraki-Moud, F.; Anjos-Afonso, F.; Pearce, D.J.; Allen, K.; Ridler, C.; Lillington, D.; Oakervee, H.; Cavenagh, J.; Agrawal, S.G.; et al. Anti-CD38 antibody-mediated clearance of human repopulating cells masks the heterogeneity of leukemia-initiating cells. Blood 2008, 112, 568-575. [CrossRef] [PubMed]

39. Terwijn, M.; Zeijlemaker, W.; Kelder, A.; Rutten, A.P.; Snel, A.N.; Scholten, W.J.; Pabst, T.; Verhoef, G.; Lowenberg, B.; Zweegman, S.; et al. Leukemic stem cell frequency: A strong biomarker for clinical outcome in acute myeloid leukemia. PLoS ONE 2014, 9, e107587. [CrossRef]

40. Van Rhenen, A.; Feller, N.; Kelder, A.; Westra, A.H.; Rombouts, E.; Zweegman, S.; van der Pol, M.A.; Waisfisz, Q.; Ossenkoppele, G.J.; Schuurhuis, G.J. High stem cell frequency in acute myeloid leukemia at diagnosis predicts high minimal residual disease and poor survival. Clin. Cancer Res. 2005, 11, 6520-6527. [CrossRef]

41. Goardon, N.; Marchi, E.; Atzberger, A.; Quek, L.; Schuh, A.; Soneji, S.; Woll, P.; Mead, A.; Alford, K.A.; Rout, R.; et al. Coexistence of LMPP-like and GMP-like leukemia stem cells in acute myeloid leukemia. Cancer Cell 2011, 19, 138-152. [CrossRef] 
42. Ho, T.C.; LaMere, M.; Stevens, B.M.; Ashton, J.M.; Myers, J.R.; O’Dwyer, K.M.; Liesveld, J.L.; Mendler, J.H.; Guzman, M.; Morrissette, J.D.; et al. Evolution of acute myelogenous leukemia stem cell properties after treatment and progression. Blood 2016, 128, 1671-1678. [CrossRef]

43. Behbehani, G.K.; Samusik, N.; Bjornson, Z.B.; Fantl, W.J.; Medeiros, B.C.; Nolan, G.P. Mass Cytometric Functional Profiling of Acute Myeloid Leukemia Defines Cell-Cycle and Immunophenotypic Properties That Correlate with Known Responses to Therapy. Cancer Discov. 2015, 5, 988-1003. [CrossRef]

44. Herrmann, H.; Sadovnik, I.; Eisenwort, G.; Rulicke, T.; Blatt, K.; Herndlhofer, S.; Willmann, M.; Stefanzl, G.; Baumgartner, S.; Greiner, G.; et al. Delineation of target expression profiles in CD34+/CD38- and CD34+/CD38+ stem and progenitor cells in AML and CML. Blood Adv. 2020, 4, 5118-5132. [CrossRef] [PubMed]

45. Pinho, S.; Frenette, P.S. Haematopoietic stem cell activity and interactions with the niche. Nat. Rev. Mol. Cell Biol. 2019, 20, 303-320. [CrossRef]

46. Colmone, A.; Amorim, M.; Pontier, A.L.; Wang, S.; Jablonski, E.; Sipkins, D.A. Leukemic cells create bone marrow niches that disrupt the behavior of normal hematopoietic progenitor cells. Science 2008, 322, 1861-1865. [CrossRef] [PubMed]

47. Mohammadi Najafabadi, M.; Shamsasenjan, K.; Akbarzadehalaleh, P. Angiogenesis Status in Patients with Acute Myeloid Leukemia: From Diagnosis to Post-hematopoietic Stem Cell Transplantation. Int. J. Organ. Transplant. Med. 2017,8 , 57-67.

48. Chen, C.; Liu, Y.; Hua, M.; Li, X.; Ji, C.; Ma, D. Neuropathy correlated with imbalanced Foxp3/IL-17 in bone marrow microenvironment of patients with acute myeloid leukemia. Oncotarget 2016, 7, 24455-24465. [CrossRef]

49. Kim, J.A.; Shim, J.S.; Lee, G.Y.; Yim, H.W.; Kim, T.M.; Kim, M.; Leem, S.H.; Lee, J.W.; Min, C.K.; Oh, I.H. Microenvironmental remodeling as a parameter and prognostic factor of heterogeneous leukemogenesis in acute myelogenous leukemia. Cancer Res. 2015, 75, 2222-2231. [CrossRef] [PubMed]

50. Krevvata, M.; Silva, B.C.; Manavalan, J.S.; Galan-Diez, M.; Kode, A.; Matthews, B.G.; Park, D.; Zhang, C.A.; Galili, N.; Nickolas, T.L.; et al. Inhibition of leukemia cell engraftment and disease progression in mice by osteoblasts. Blood 2014, 124, 2834-2846. [CrossRef]

51. Boyd, A.L.; Reid, J.C.; Salci, K.R.; Aslostovar, L.; Benoit, Y.D.; Shapovalova, Z.; Nakanishi, M.; Porras, D.P.; Almakadi, M.; Campbell, C.J.V.; et al. Acute myeloid leukaemia disrupts endogenous myelo-erythropoiesis by compromising the adipocyte bone marrow niche. Nat. Cell Biol. 2017, 19, 1336-1347. [CrossRef]

52. Bernasconi, P.; Borsani, O. Targeting Leukemia Stem Cell-Niche Dynamics: A New Challenge in AML Treatment. J. Oncol. 2019, 2019, 8323592. [CrossRef] [PubMed]

53. Kokkaliaris, K.D.; Scadden, D.T. Cell interactions in the bone marrow microenvironment affecting myeloid malignancies. Blood Adv. 2020, 4, 3795-3803. [CrossRef]

54. Frisch, B.J.; Ashton, J.M.; Xing, L.; Becker, M.W.; Jordan, C.T.; Calvi, L.M. Functional inhibition of osteoblastic cells in an in vivo mouse model of myeloid leukemia. Blood 2012, 119, 540-550. [CrossRef]

55. Hanoun, M.; Zhang, D.; Mizoguchi, T.; Pinho, S.; Pierce, H.; Kunisaki, Y.; Lacombe, J.; Armstrong, S.A.; Duhrsen, U.; Frenette, P.S. Acute myelogenous leukemia-induced sympathetic neuropathy promotes malignancy in an altered hematopoietic stem cell niche. Cell Stem Cell 2014, 15, 365-375. [CrossRef]

56. Baryawno, N.; Przybylski, D.; Kowalczyk, M.S.; Kfoury, Y.; Severe, N.; Gustafsson, K.; Kokkaliaris, K.D.; Mercier, F.; Tabaka, M.; Hofree, M.; et al. A Cellular Taxonomy of the Bone Marrow Stroma in Homeostasis and Leukemia. Cell 2019, 177, 1915-1932 e1916. [CrossRef] [PubMed]

57. Isidori, A.; Salvestrini, V.; Ciciarello, M.; Loscocco, F.; Visani, G.; Parisi, S.; Lecciso, M.; Ocadlikova, D.; Rossi, L.; Gabucci, E.; et al. The role of the immunosuppressive microenvironment in acute myeloid leukemia development and treatment. Expert Rev. Hematol. 2014, 7, 807-818. [CrossRef]

58. Ladikou, E.E.; Sivaloganathan, H.; Pepper, A.; Chevassut, T. Acute Myeloid Leukaemia in Its Niche: The Bone Marrow Microenvironment in Acute Myeloid Leukaemia. Curr. Oncol. Rep. 2020, 22, 27. [CrossRef]

59. Christopher, M.J.; Petti, A.A.; Rettig, M.P.; Miller, C.A.; Chendamarai, E.; Duncavage, E.J.; Klco, J.M.; Helton, N.M.; O’Laughlin, M.; Fronick, C.C.; et al. Immune Escape of Relapsed AML Cells after Allogeneic Transplantation. N. Engl. J. Med. 2018, 379, 2330-2341. [CrossRef]

60. Curran, E.K.; Godfrey, J.; Kline, J. Mechanisms of Immune Tolerance in Leukemia and Lymphoma. Trends Immunol. 2017, 38, 513-525. [CrossRef]

61. Paczulla, A.M.; Rothfelder, K.; Raffel, S.; Konantz, M.; Steinbacher, J.; Wang, H.; Tandler, C.; Mbarga, M.; Schaefer, T.; Falcone, M.; et al. Absence of NKG2D ligands defines leukaemia stem cells and mediates their immune evasion. Nature 2019, 572, 254-259. [CrossRef] [PubMed]

62. Schepers, K.; Campbell, T.B.; Passegue, E. Normal and leukemic stem cell niches: Insights and therapeutic opportunities. Cell Stem Cell 2015, 16, 254-267. [CrossRef]

63. Zhou, H.S.; Carter, B.Z.; Andreeff, M. Bone marrow niche-mediated survival of leukemia stem cells in acute myeloid leukemia: Yin and Yang. Cancer Biol. Med. 2016, 13, 248-259. [CrossRef]

64. Theocharides, A.P.; Jin, L.; Cheng, P.Y.; Prasolava, T.K.; Malko, A.V.; Ho, J.M.; Poeppl, A.G.; van Rooijen, N.; Minden, M.D.; Danska, J.S.; et al. Disruption of SIRPalpha signaling in macrophages eliminates human acute myeloid leukemia stem cells in xenografts. J. Exp. Med. 2012, 209, 1883-1899. [CrossRef] 
65. Villatoro, A.; Konieczny, J.; Cuminetti, V.; Arranz, L. Leukemia Stem Cell Release from the Stem Cell Niche to Treat Acute Myeloid Leukemia. Front. Cell Dev. Biol. 2020, 8, 607. [CrossRef] [PubMed]

66. Huan, J.; Hornick, N.I.; Shurtleff, M.J.; Skinner, A.M.; Goloviznina, N.A.; Roberts, C.T., Jr.; Kurre, P. RNA trafficking by acute myelogenous leukemia exosomes. Cancer Res. 2013, 73, 918-929. [CrossRef]

67. Shafat, M.S.; Oellerich, T.; Mohr, S.; Robinson, S.D.; Edwards, D.R.; Marlein, C.R.; Piddock, R.E.; Fenech, M.; Zaitseva, L.; Abdul-Aziz, A.; et al. Leukemic blasts program bone marrow adipocytes to generate a protumoral microenvironment. Blood 2017, 129, 1320-1332. [CrossRef]

68. Bruserud, O.; Ryningen, A.; Wergeland, L.; Glenjen, N.I.; Gjertsen, B.T. Osteoblasts increase proliferation and release of proangiogenic interleukin 8 by native human acute myelogenous leukemia blasts. Haematologica 2004, 89, 391-402. [PubMed]

69. Zhai, Y.; Zhang, J.; Wang, H.; Lu, W.; Liu, S.; Yu, Y.; Weng, W.; Ding, Z.; Zhu, Q.; Shi, J. Growth differentiation factor 15 contributes to cancer-associated fibroblasts-mediated chemo-protection of AML cells. J. Exp. Clin. Cancer Res. 2016, 35, 147. [CrossRef]

70. Duan, C.W.; Shi, J.; Chen, J.; Wang, B.; Yu, Y.H.; Qin, X.; Zhou, X.C.; Cai, Y.J.; Li, Z.Q.; Zhang, F.; et al. Leukemia propagating cells rebuild an evolving niche in response to therapy. Cancer Cell 2014, 25, 778-793. [CrossRef] [PubMed]

71. Takam Kamga, P.; Bassi, G.; Cassaro, A.; Midolo, M.; Di Trapani, M.; Gatti, A.; Carusone, R.; Resci, F.; Perbellini, O.; Gottardi, M.; et al. Notch signalling drives bone marrow stromal cell-mediated chemoresistance in acute myeloid leukemia. Oncotarget 2016, 7 , 21713-21727. [CrossRef] [PubMed]

72. Xia, B.; Tian, C.; Guo, S.; Zhang, L.; Zhao, D.; Qu, F.; Zhao, W.; Wang, Y.; Wu, X.; Da, W.; et al. c-Myc plays part in drug resistance mediated by bone marrow stromal cells in acute myeloid leukemia. Leuk. Res. 2015, 39, 92-99. [CrossRef]

73. Konopleva, M.; Konoplev, S.; Hu, W.; Zaritskey, A.Y.; Afanasiev, B.V.; Andreeff, M. Stromal cells prevent apoptosis of AML cells by up-regulation of anti-apoptotic proteins. Leukemia 2002, 16, 1713-1724. [CrossRef]

74. Moschoi, R.; Imbert, V.; Nebout, M.; Chiche, J.; Mary, D.; Prebet, T.; Saland, E.; Castellano, R.; Pouyet, L.; Collette, Y.; et al Protective mitochondrial transfer from bone marrow stromal cells to acute myeloid leukemic cells during chemotherapy. Blood 2016, 128, 253-264. [CrossRef]

75. Matsunaga, T.; Imataki, O.; Torii, E.; Kameda, T.; Shide, K.; Shimoda, H.; Kamiunten, A.; Sekine, M.; Taniguchi, Y.; Yamamoto, S.; et al. Elevated HIF-1alpha expression of acute myelogenous leukemia stem cells in the endosteal hypoxic zone may be a cause of minimal residual disease in bone marrow after chemotherapy. Leuk. Res. 2012, 36, e122-e124. [CrossRef]

76. Drolle, H.; Wagner, M.; Vasold, J.; Kutt, A.; Deniffel, C.; Sotlar, K.; Sironi, S.; Herold, T.; Rieger, C.; Fiegl, M. Hypoxia regulates proliferation of acute myeloid leukemia and sensitivity against chemotherapy. Leuk. Res. 2015, 39, 779-785. [CrossRef]

77. Bray, L.J.; Binner, M.; Korner, Y.; von Bonin, M.; Bornhauser, M.; Werner, C. A three-dimensional ex vivo tri-culture model mimics cell-cell interactions between acute myeloid leukemia and the vascular niche. Haematologica 2017, 102, 1215-1226. [CrossRef]

78. Ma, C.; Witkowski, M.T.; Harris, J.; Dolgalev, I.; Sreeram, S.; Qian, W.; Tong, J.; Chen, X.; Aifantis, I.; Chen, W. Leukemia-on-a-chip: Dissecting the chemoresistance mechanisms in B cell acute lymphoblastic leukemia bone marrow niche. Sci. Adv. 2020, 6. [CrossRef] [PubMed]

79. Gross, G.; Gorochov, G.; Waks, T.; Eshhar, Z. Generation of effector T cells expressing chimeric T cell receptor with antibody type-specificity. Transplant. Proc. 1989, 21, 127-130. [PubMed]

80. Gross, G.; Waks, T.; Eshhar, Z. Expression of immunoglobulin-T-cell receptor chimeric molecules as functional receptors with antibody-type specificity. Proc. Natl. Acad. Sci. USA 1989, 86, 10024-10028. [CrossRef]

81. Eshhar, Z.; Waks, T.; Gross, G.; Schindler, D.G. Specific activation and targeting of cytotoxic lymphocytes through chimeric single chains consisting of antibody-binding domains and the gamma or zeta subunits of the immunoglobulin and T-cell receptors. Proc. Natl. Acad. Sci. USA 1993, 90, 720-724. [CrossRef] [PubMed]

82. Jayaraman, J.; Mellody, M.P.; Hou, A.J.; Desai, R.P.; Fung, A.W.; Pham, A.H.T.; Chen, Y.Y.; Zhao, W. CAR-T design: Elements and their synergistic function. EBioMedicine 2020, 58, 102931. [CrossRef]

83. Sadelain, M.; Riviere, I.; Riddell, S. Therapeutic T cell engineering. Nature 2017, 545, 423-431. [CrossRef]

84. Depil, S.; Duchateau, P.; Grupp, S.A.; Mufti, G.; Poirot, L. 'Off-the-shelf' allogeneic CAR T cells: Development and challenges. Nat. Rev. Drug Discov. 2020, 19, 185-199. [CrossRef]

85. Kalos, M.; Levine, B.L.; Porter, D.L.; Katz, S.; Grupp, S.A.; Bagg, A.; June, C.H. T cells with chimeric antigen receptors have potent antitumor effects and can establish memory in patients with advanced leukemia. Sci. Transl. Med. 2011, 3, 95ra73. [CrossRef] [PubMed]

86. Porter, D.L.; Levine, B.L.; Kalos, M.; Bagg, A.; June, C.H. Chimeric antigen receptor-modified T cells in chronic lymphoid leukemia. N. Engl. J. Med. 2011, 365, 725-733. [CrossRef]

87. Brentjens, R.J.; Riviere, I.; Park, J.H.; Davila, M.L.; Wang, X.; Stefanski, J.; Taylor, C.; Yeh, R.; Bartido, S.; Borquez-Ojeda, O.; et al. Safety and persistence of adoptively transferred autologous CD19-targeted T cells in patients with relapsed or chemotherapy refractory B-cell leukemias. Blood 2011, 118, 4817-4828. [CrossRef] [PubMed]

88. Brentjens, R.J.; Davila, M.L.; Riviere, I.; Park, J.; Wang, X.; Cowell, L.G.; Bartido, S.; Stefanski, J.; Taylor, C.; Olszewska, M.; et al. CD19-targeted $\mathrm{T}$ cells rapidly induce molecular remissions in adults with chemotherapy-refractory acute lymphoblastic leukemia. Sci. Transl. Med. 2013, 5, 177ra138. [CrossRef] [PubMed]

89. Grupp, S.A.; Kalos, M.; Barrett, D.; Aplenc, R.; Porter, D.L.; Rheingold, S.R.; Teachey, D.T.; Chew, A.; Hauck, B.; Wright, J.F.; et al. Chimeric antigen receptor-modified T cells for acute lymphoid leukemia. N. Engl. J. Med. 2013, 368, 1509-1518. [CrossRef] [PubMed] 
90. Davila, M.L.; Riviere, I.; Wang, X.; Bartido, S.; Park, J.; Curran, K.; Chung, S.S.; Stefanski, J.; Borquez-Ojeda, O.; Olszewska, M.; et al. Efficacy and toxicity management of 19-28z CAR T cell therapy in B cell acute lymphoblastic leukemia. Sci. Transl. Med. 2014, 6, 224ra225. [CrossRef]

91. Maude, S.L.; Frey, N.; Shaw, P.A.; Aplenc, R.; Barrett, D.M.; Bunin, N.J.; Chew, A.; Gonzalez, V.E.; Zheng, Z.; Lacey, S.F.; et al. Chimeric antigen receptor T cells for sustained remissions in leukemia. N. Engl. J. Med. 2014, 371, 1507-1517. [CrossRef]

92. Lee, D.W.; Kochenderfer, J.N.; Stetler-Stevenson, M.; Cui, Y.K.; Delbrook, C.; Feldman, S.A.; Fry, T.J.; Orentas, R.; Sabatino, M.; Shah, N.N.; et al. T cells expressing CD19 chimeric antigen receptors for acute lymphoblastic leukaemia in children and young adults: A phase 1 dose-escalation trial. Lancet 2015, 385, 517-528. [CrossRef]

93. Jensen, M.C.; Popplewell, L.; Cooper, L.J.; DiGiusto, D.; Kalos, M.; Ostberg, J.R.; Forman, S.J. Antitransgene rejection responses contribute to attenuated persistence of adoptively transferred CD20/CD19-specific chimeric antigen receptor redirected T cells in humans. Biol. Blood Marrow Transplant. 2010, 16, 1245-1256. [CrossRef]

94. Savoldo, B.; Ramos, C.A.; Liu, E.; Mims, M.P.; Keating, M.J.; Carrum, G.; Kamble, R.T.; Bollard, C.M.; Gee, A.P.; Mei, Z.; et al. CD28 costimulation improves expansion and persistence of chimeric antigen receptor-modified T cells in lymphoma patients. $J$. Clin. Investig. 2011, 121, 1822-1826. [CrossRef]

95. Kochenderfer, J.N.; Wilson, W.H.; Janik, J.E.; Dudley, M.E.; Stetler-Stevenson, M.; Feldman, S.A.; Maric, I.; Raffeld, M.; Nathan, D.A.; Lanier, B.J.; et al. Eradication of B-lineage cells and regression of lymphoma in a patient treated with autologous T cells genetically engineered to recognize CD19. Blood 2010, 116, 4099-4102. [CrossRef] [PubMed]

96. Kochenderfer, J.N.; Dudley, M.E.; Feldman, S.A.; Wilson, W.H.; Spaner, D.E.; Maric, I.; Stetler-Stevenson, M.; Phan, G.Q.; Hughes, M.S.; Sherry, R.M.; et al. B-cell depletion and remissions of malignancy along with cytokine-associated toxicity in a clinical trial of anti-CD19 chimeric-antigen-receptor-transduced T cells. Blood 2012, 119, 2709-2720. [CrossRef] [PubMed]

97. Kochenderfer, J.N.; Dudley, M.E.; Kassim, S.H.; Somerville, R.P.; Carpenter, R.O.; Stetler-Stevenson, M.; Yang, J.C.; Phan, G.Q.; Hughes, M.S.; Sherry, R.M.; et al. Chemotherapy-refractory diffuse large B-cell lymphoma and indolent B-cell malignancies can be effectively treated with autologous T cells expressing an anti-CD19 chimeric antigen receptor. J. Clin. Oncol. 2015, 33, 540-549. [CrossRef] [PubMed]

98. Kochenderfer, J.N.; Somerville, R.P.T.; Lu, T.; Yang, J.C.; Sherry, R.M.; Feldman, S.A.; McIntyre, L.; Bot, A.; Rossi, J.; Lam, N.; et al. Long-Duration Complete Remissions of Diffuse Large B Cell Lymphoma after Anti-CD19 Chimeric Antigen Receptor T Cell Therapy. Mol. Ther. 2017, 25, 2245-2253. [CrossRef] [PubMed]

99. Locke, F.L.; Neelapu, S.S.; Bartlett, N.L.; Siddiqi, T.; Chavez, J.C.; Hosing, C.M.; Ghobadi, A.; Budde, L.E.; Bot, A.; Rossi, J.M.; et al. Phase 1 Results of ZUMA-1: A Multicenter Study of KTE-C19 Anti-CD19 CAR T Cell Therapy in Refractory Aggressive Lymphoma. Mol. Ther. 2017, 25, 285-295. [CrossRef]

100. Maude, S.L.; Laetsch, T.W.; Buechner, J.; Rives, S.; Boyer, M.; Bittencourt, H.; Bader, P.; Verneris, M.R.; Stefanski, H.E.; Myers, G.D.; et al. Tisagenlecleucel in Children and Young Adults with B-Cell Lymphoblastic Leukemia. N. Engl. J. Med. 2018, 378, 439-448. [CrossRef]

101. Schuster, S.J.; Svoboda, J.; Chong, E.A.; Nasta, S.D.; Mato, A.R.; Anak, O.; Brogdon, J.L.; Pruteanu-Malinici, I.; Bhoj, V.; Landsburg, D.; et al. Chimeric Antigen Receptor T Cells in Refractory B-Cell Lymphomas. N. Engl. J. Med. 2017, 377, 2545-2554. [CrossRef] [PubMed]

102. Schuster, S.J.; Bishop, M.R.; Tam, C.S.; Waller, E.K.; Borchmann, P.; McGuirk, J.P.; Jager, U.; Jaglowski, S.; Andreadis, C.; Westin, J.R.; et al. Tisagenlecleucel in Adult Relapsed or Refractory Diffuse Large B-Cell Lymphoma. N. Engl. J. Med. 2019, 380, 45-56. [CrossRef]

103. Neelapu, S.S.; Locke, F.L.; Bartlett, N.L.; Lekakis, L.J.; Miklos, D.B.; Jacobson, C.A.; Braunschweig, I.; Oluwole, O.O.; Siddiqi, T.; Lin, Y.; et al. Axicabtagene Ciloleucel CAR T-Cell Therapy in Refractory Large B-Cell Lymphoma. N. Engl. J. Med. 2017, 377, 2531-2544. [CrossRef] [PubMed]

104. Park, J.H.; Riviere, I.; Gonen, M.; Wang, X.; Senechal, B.; Curran, K.J.; Sauter, C.; Wang, Y.; Santomasso, B.; Mead, E.; et al. Long-Term Follow-up of CD19 CAR Therapy in Acute Lymphoblastic Leukemia. N. Engl. J. Med. 2018, 378, 449-459. [CrossRef] [PubMed]

105. Ritchie, D.S.; Neeson, P.J.; Khot, A.; Peinert, S.; Tai, T.; Tainton, K.; Chen, K.; Shin, M.; Wall, D.M.; Honemann, D.; et al. Persistence and efficacy of second generation CAR T cell against the LeY antigen in acute myeloid leukemia. Mol. Ther. 2013, 21, 2122-2129. [CrossRef]

106. Fiorenza, S.; Turtle, C.J. CAR-T Cell Therapy for Acute Myeloid Leukemia: Preclinical Rationale, Current Clinical Progress, and Barriers to Success. BioDrugs 2021, 35, 281-302. [CrossRef] [PubMed]

107. Bu, C.; Peng, Z.; Luo, M.; Li, G.; Li, C. Phase I Clinical Trial of Autologous CLL1 CAR-T Therapy for Pediatric Patients with Relapsed and Refractory Acute Myeloid Leukemia. Blood 2020, 136, 13. [CrossRef]

108. Chen, L.; Mao, H.; Zhang, J.; Chu, J.; Devine, S.; Caligiuri, M.A.; Yu, J. Targeting FLT3 by chimeric antigen receptor T cells for the treatment of acute myeloid leukemia. Leukemia 2017, 31, 1830-1834. [CrossRef]

109. Wang, Y.; Xu, Y.; Li, S.; Liu, J.; Xing, Y.; Xing, H.; Tian, Z.; Tang, K.; Rao, Q.; Wang, M.; et al. Targeting FLT3 in acute myeloid leukemia using ligand-based chimeric antigen receptor-engineered T cells. J. Hematol. Oncol. 2018, 11, 60. [CrossRef]

110. Jetani, H.; Garcia-Cadenas, I.; Nerreter, T.; Thomas, S.; Rydzek, J.; Meijide, J.B.; Bonig, H.; Herr, W.; Sierra, J.; Einsele, H.; et al. CAR T-cells targeting FLT3 have potent activity against FLT3(-)ITD(+) AML and act synergistically with the FLT3-inhibitor crenolanib. Leukemia 2018, 32, 1168-1179. [CrossRef] 
111. Yoshida, T.; Mihara, K.; Takei, Y.; Yanagihara, K.; Kubo, T.; Bhattacharyya, J.; Imai, C.; Mino, T.; Takihara, Y.; Ichinohe, T. All-trans retinoic acid enhances cytotoxic effect of T cells with an anti-CD38 chimeric antigen receptor in acute myeloid leukemia. Clin. Transl. Immunol. 2016, 5, e116. [CrossRef] [PubMed]

112. Lynn, R.C.; Poussin, M.; Kalota, A.; Feng, Y.; Low, P.S.; Dimitrov, D.S.; Powell, D.J., Jr. Targeting of folate receptor beta on acute myeloid leukemia blasts with chimeric antigen receptor-expressing T cells. Blood 2015, 125, 3466-3476. [CrossRef]

113. Lynn, R.C.; Feng, Y.; Schutsky, K.; Poussin, M.; Kalota, A.; Dimitrov, D.S.; Powell, D.J., Jr. High-affinity FRbeta-specific CAR T cells eradicate AML and normal myeloid lineage without HSC toxicity. Leukemia 2016, 30, 1355-1364. [CrossRef]

114. Rafiq, S.; Purdon, T.J.; Daniyan, A.F.; Koneru, M.; Dao, T.; Liu, C.; Scheinberg, D.A.; Brentjens, R.J. Optimized T-cell receptormimic chimeric antigen receptor T cells directed toward the intracellular Wilms Tumor 1 antigen. Leukemia 2017, 31, 1788-1797. [CrossRef] [PubMed]

115. Kurosawa, N.; Midorikawa, A.; Ida, K.; Fudaba, Y.W.; Isobe, M. Development of a T-cell receptor mimic antibody targeting a novel Wilms tumor 1-derived peptide and analysis of its specificity. Cancer Sci. 2020, 111, 3516-3526. [CrossRef]

116. Lichtman, E.I.; Du, H.; Shou, P.; Song, F.; Suzuki, K.; Ahn, S.; Li, G.; Ferrone, S.; Su, L.; Savoldo, B.; et al. Preclinical Evaluation of B7-H3-specific Chimeric Antigen Receptor T Cells for the Treatment of Acute Myeloid Leukemia. Clin. Cancer Res. 2021. [CrossRef] [PubMed]

117. Zhang, Z.; Jiang, C.; Liu, Z.; Yang, M.; Tang, X.; Wang, Y.; Zheng, M.; Huang, J.; Zhong, K.; Zhao, S.; et al. B7-H3-Targeted CAR-T Cells Exhibit Potent Antitumor Effects on Hematologic and Solid Tumors. Mol. Ther. Oncolytics 2020, 17, 180-189. [CrossRef]

118. Leick, M.; Scarfò, I.; Choi, B.D.; Larson, R.; Bouffard, A.A.; Castano, A.; Cabral, M.L.; Schmidts, A.; Frigault, M.J.; Maus, M.V. Use of CD70 Targeted Chimeric Antigen Receptor (CAR) T Cells for the Treatment of Acute Myeloid Leukemia (AML). Blood 2019, 134, 4443. [CrossRef]

119. Sauer, T.; Parikh, K.; Sharma, S.; Omer, B.; Sedloev, D.N.; Chen, Q.; Angenendt, L.; Schliemann, C.; Schmitt, M.; Muller-Tidow, C.; et al. CD70-specific CAR T-cells have potent activity against Acute Myeloid Leukemia (AML) without HSC toxicity. Blood 2021. [CrossRef]

120. Gomes-Silva, D.; Atilla, E.; Atilla, P.A.; Mo, F.; Tashiro, H.; Srinivasan, M.; Lulla, P.; Rouce, R.H.; Cabral, J.M.S.; Ramos, C.A.; et al. CD7 CAR T Cells for the Therapy of Acute Myeloid Leukemia. Mol. Ther. 2019, 27, 272-280. [CrossRef]

121. Mardiana, S.; Gill, S. CAR T Cells for Acute Myeloid Leukemia: State of the Art and Future Directions. Front. Oncol. 2020, 10, 697. [CrossRef] [PubMed]

122. Tasian, S.K. Acute myeloid leukemia chimeric antigen receptor T-cell immunotherapy: How far up the road have we traveled? Ther. Adv. Hematol. 2018, 9, 135-148. [CrossRef]

123. Cheng, J.; Zhao, L.; Zhang, Y.; Qin, Y.; Guan, Y.; Zhang, T.; Liu, C.; Zhou, J. Understanding the Mechanisms of Resistance to CAR T-Cell Therapy in Malignancies. Front. Oncol. 2019, 9, 1237. [CrossRef] [PubMed]

124. Charrot, S.; Hallam, S. CAR-T Cells: Future Perspectives. Hemasphere 2019, 3, e188. [CrossRef]

125. Rodriguez-Garcia, A.; Palazon, A.; Noguera-Ortega, E.; Powell, D.J., Jr.; Guedan, S. CAR-T Cells Hit the Tumor Microenvironment: Strategies to Overcome Tumor Escape. Front. Immunol. 2020, 11, 1109. [CrossRef]

126. Perna, F.; Berman, S.H.; Soni, R.K.; Mansilla-Soto, J.; Eyquem, J.; Hamieh, M.; Hendrickson, R.C.; Brennan, C.W.; Sadelain, M. Integrating Proteomics and Transcriptomics for Systematic Combinatorial Chimeric Antigen Receptor Therapy of AML. Cancer Cell 2017, 32, 506-519. [CrossRef] [PubMed]

127. Wang, Q.S.; Wang, Y.; Lv, H.Y.; Han, Q.W.; Fan, H.; Guo, B.; Wang, L.L.; Han, W.D. Treatment of CD33-directed chimeric antigen receptor-modified $\mathrm{T}$ cells in one patient with relapsed and refractory acute myeloid leukemia. Mol. Ther. 2015, 23, 184-191. [CrossRef]

128. Budde, L.; Song, J.Y.; Kim, Y.; Blanchard, S.; Wagner, J.; Stein, A.S.; Weng, L.; Del Real, M.; Hernandez, R.; Marcucci, E.; et al. Remissions of Acute Myeloid Leukemia and Blastic Plasmacytoid Dendritic Cell Neoplasm Following Treatment with CD123-Specific CAR T Cells: A First-in-Human Clinical Trial. Blood 2017, 130, 811. [CrossRef]

129. Xie, G.; Ivica, N.A.; Jia, B.; Li, Y.; Dong, H.; Liang, Y.; Brown, D.; Rizwan, R.; Chen, J. CAR-T cells targeting a nucleophosmin neoepitope exhibit potent specific activity in mouse models of acute myeloid leukaemia. Nat. Biomed. Eng. 2020. [CrossRef]

130. Graf, C.; Heidel, F.; Tenzer, S.; Radsak, M.P.; Solem, F.K.; Britten, C.M.; Huber, C.; Fischer, T.; Wolfel, T. A neoepitope generated by an FLT3 internal tandem duplication (FLT3-ITD) is recognized by leukemia-reactive autologous CD8+ T cells. Blood 2007, 109, 2985-2988. [CrossRef] [PubMed]

131. Goswami, M.; Hourigan, C.S. Novel Antigen Targets for Immunotherapy of Acute Myeloid Leukemia. Curr. Drug Targets 2017, 18, 296-303. [CrossRef] [PubMed]

132. Casucci, M.; Nicolis di Robilant, B.; Falcone, L.; Camisa, B.; Norelli, M.; Genovese, P.; Gentner, B.; Gullotta, F.; Ponzoni, M.; Bernardi, M.; et al. CD44v6-targeted T cells mediate potent antitumor effects against acute myeloid leukemia and multiple myeloma. Blood 2013, 122, 3461-3472. [CrossRef]

133. Depreter, B.; Weening, K.E.; Vandepoele, K.; Essand, M.; De Moerloose, B.; Themeli, M.; Cloos, J.; Hanekamp, D.; Moors, I.; D'Hont, I.; et al. TARP is an immunotherapeutic target in acute myeloid leukemia expressed in the leukemic stem cell compartment. Haematologica 2020, 105, 1306-1316. [CrossRef]

134. He, X.; Feng, Z.; Ma, J.; Ling, S.; Cao, Y.; Gurung, B.; Wu, Y.; Katona, B.W.; O’Dwyer, K.P.; Siegel, D.L.; et al. Bispecific and split CAR T cells targeting CD13 and TIM3 eradicate acute myeloid leukemia. Blood 2020, 135, 713-723. [CrossRef] [PubMed] 
135. Kim, M.Y.; Yu, K.R.; Kenderian, S.S.; Ruella, M.; Chen, S.; Shin, T.H.; Aljanahi, A.A.; Schreeder, D.; Klichinsky, M.; Shestova, O.; et al. Genetic Inactivation of CD33 in Hematopoietic Stem Cells to Enable CAR T Cell Immunotherapy for Acute Myeloid Leukemia. Cell 2018, 173, 1439-1453. [CrossRef] [PubMed]

136. Haubner, S.; Perna, F.; Kohnke, T.; Schmidt, C.; Berman, S.; Augsberger, C.; Schnorfeil, F.M.; Krupka, C.; Lichtenegger, F.S.; Liu, X.; et al. Coexpression profile of leukemic stem cell markers for combinatorial targeted therapy in AML. Leukemia 2019, 33, 64-74. [CrossRef]

137. Arcangeli, S.; Rotiroti, M.C.; Bardelli, M.; Simonelli, L.; Magnani, C.F.; Biondi, A.; Biagi, E.; Tettamanti, S.; Varani, L. Balance of Anti-CD123 Chimeric Antigen Receptor Binding Affinity and Density for the Targeting of Acute Myeloid Leukemia. Mol. Ther. 2017, 25, 1933-1945. [CrossRef]

138. Kenderian, S.S.; Ruella, M.; Shestova, O.; Klichinsky, M.; Aikawa, V.; Morrissette, J.J.; Scholler, J.; Song, D.; Porter, D.L.; Carroll, M.; et al. CD33-specific chimeric antigen receptor $\mathrm{T}$ cells exhibit potent preclinical activity against human acute myeloid leukemia. Leukemia 2015, 29, 1637-1647. [CrossRef]

139. Petrov, J.C.; Wada, M.; Pinz, K.G.; Yan, L.E.; Chen, K.H.; Shuai, X.; Liu, H.; Chen, X.; Leung, L.H.; Salman, H.; et al. Compound CAR T-cells as a double-pronged approach for treating acute myeloid leukemia. Leukemia 2018, 32, 1317-1326. [CrossRef] [PubMed]

140. Tasian, S.K.; Kenderian, S.S.; Shen, F.; Ruella, M.; Shestova, O.; Kozlowski, M.; Li, Y.; Schrank-Hacker, A.; Morrissette, J.J.D.; Carroll, M.; et al. Optimized depletion of chimeric antigen receptor T cells in murine xenograft models of human acute myeloid leukemia. Blood 2017, 129, 2395-2407. [CrossRef]

141. Cummins, K.D.; Frey, N.; Nelson, A.M.; Schmidt, A.; Luger, S.; Isaacs, R.E.; Lacey, S.F.; Hexner, E.; Melenhorst, J.J.; June, C.H.; et al. Treating Relapsed / Refractory (RR) AML with Biodegradable Anti-CD123 CAR Modified T Cells. Blood 2017, 130, 1359. [CrossRef]

142. Willier, S.; Rothamel, P.; Hastreiter, M.; Wilhelm, J.; Stenger, D.; Blaeschke, F.; Rohlfs, M.; Kaeuferle, T.; Schmid, I.; Albert, M.H.; et al. CLEC12A and CD33 co-expression as preferential target on pediatric AML for combinatorial immunotherapy. Blood 2021, 137, 1037-1049. [CrossRef] [PubMed]

143. Danylesko, I.; Jacoby, E.; Yerushalmi, R.; Shem-Tov, N.; Besser, M.J.; Vernitsky, H.; Marcu-Malina, V.; Shimoni, A.; Avigdor, A.; Nagler, A. Remission of acute myeloid leukemia with $\mathrm{t}(8 ; 21)$ following CD19 CAR T-cells. Leukemia 2020, 34, 1939-1942. [CrossRef] [PubMed]

144. Al-Mawali, A.; Gillis, D.; Lewis, I. Immunoprofiling of leukemic stem cells CD34+/CD38-/CD123+ delineate FLT3/ITD-positive clones. J. Hematol. Oncol. 2016, 9, 61. [CrossRef] [PubMed]

145. Liu, F.; Zhang, H.; Sun, L.; Li, Y.; Zhang, S.; He, G.; Yi, H.; Wada, M.; Pinz, K.G.; Chen, K.H.; et al. First-in-human CLL1-CD33 compound CAR (cCAR) T cell therapy in relapsed and refractory acute myeloid leukemia. In Proceedings of the 25th EHA Annual Congress, Frankfurt, Germany, 12 June 2020.

146. Epperly, R.; Gottschalk, S.; Velasquez, M.P. A Bump in the Road: How the Hostile AML Microenvironment Affects CAR T Cell Therapy. Front. Oncol. 2020, 10, 262. [CrossRef] [PubMed]

147. Galland, S.; Stamenkovic, I. Mesenchymal stromal cells in cancer: A review of their immunomodulatory functions and dual effects on tumor progression. J. Pathol. 2020, 250, 555-572. [CrossRef] [PubMed]

148. Teng, X.; Zhang, H.; Liang, Z.; Shao, M.; Wang, X.; Ding, L.; Cui, J.; Hu, Y.; Huang, H. Galectin-9 from Bone Marrow Mesenchymal Stromal Cells Mediates Immunosuppression on Chimeric Antigen Receptor T Cells. Blood 2019, 134, 5609. [CrossRef]

149. Imai, C.; Mihara, K.; Andreansky, M.; Nicholson, I.C.; Pui, C.H.; Geiger, T.L.; Campana, D. Chimeric receptors with 4-1BB signaling capacity provoke potent cytotoxicity against acute lymphoblastic leukemia. Leukemia 2004, 18, 676-684. [CrossRef] [PubMed]

150. Zanetti, S.R.; Romecin, P.A.; Vinyoles, M.; Juan, M.; Fuster, J.L.; Camos, M.; Querol, S.; Delgado, M.; Menendez, P. Bone marrow MSC from pediatric patients with B-ALL highly immunosuppress T-cell responses but do not compromise CD19-CAR T-cell activity. J. Immunother. Cancer 2020, 8. [CrossRef]

151. Kieffer, Y.; Hocine, H.R.; Gentric, G.; Pelon, F.; Bernard, C.; Bourachot, B.; Lameiras, S.; Albergante, L.; Bonneau, C.; Guyard, A.; et al. Single-Cell Analysis Reveals Fibroblast Clusters Linked to Immunotherapy Resistance in Cancer. Cancer Discov. 2020, 10, 1330-1351. [CrossRef]

152. Rafiq, S.; Yeku, O.O.; Jackson, H.J.; Purdon, T.J.; van Leeuwen, D.G.; Drakes, D.J.; Song, M.; Miele, M.M.; Li, Z.; Wang, P.; et al. Targeted delivery of a PD-1-blocking scFv by CAR-T cells enhances anti-tumor efficacy in vivo. Nat. Biotechnol. 2018, 36, 847-856. [CrossRef]

153. Curran, K.J.; Seinstra, B.A.; Nikhamin, Y.; Yeh, R.; Usachenko, Y.; van Leeuwen, D.G.; Purdon, T.; Pegram, H.J.; Brentjens, R.J. Enhancing antitumor efficacy of chimeric antigen receptor T cells through constitutive CD40L expression. Mol. Ther. 2015, 23, 769-778. [CrossRef] [PubMed]

154. Liu, X.; Ranganathan, R.; Jiang, S.; Fang, C.; Sun, J.; Kim, S.; Newick, K.; Lo, A.; June, C.H.; Zhao, Y.; et al. A Chimeric Switch-Receptor Targeting PD1 Augments the Efficacy of Second-Generation CAR T Cells in Advanced Solid Tumors. Cancer Res. 2016, 76, 1578-1590. [CrossRef] [PubMed]

155. Arai, Y.; Choi, U.; Corsino, C.I.; Koontz, S.M.; Tajima, M.; Sweeney, C.L.; Black, M.A.; Feldman, S.A.; Dinauer, M.C.; Malech, H.L. Myeloid Conditioning with c-kit-Targeted CAR-T Cells Enables Donor Stem Cell Engraftment. Mol. Ther. 2018, 26, 1181-1197. [CrossRef] 
156. Wang, X.; Wong, C.W.; Urak, R.; Taus, E.; Aguilar, B.; Chang, W.C.; Mardiros, A.; Budde, L.E.; Brown, C.E.; Berger, C.; et al. Comparison of naive and central memory derived CD8(+) effector cell engraftment fitness and function following adoptive transfer. Oncoimmunology 2016, 5, e1072671. [CrossRef] [PubMed]

157. Sironi, S.; Wagner, M.; Kuett, A.; Drolle, H.; Polzer, H.; Spiekermann, K.; Rieger, C.; Fiegl, M. Microenvironmental hypoxia regulates FLT3 expression and biology in AML. Sci. Rep. 2015, 5, 17550. [CrossRef] [PubMed]

158. Juillerat, A.; Marechal, A.; Filhol, J.M.; Valogne, Y.; Valton, J.; Duclert, A.; Duchateau, P.; Poirot, L. An oxygen sensitive self-decision making engineered CAR T-cell. Sci. Rep. 2017, 7, 39833. [CrossRef] [PubMed]

159. Sommer, C.; Cheng, H.Y.; Nguyen, D.; Dettling, D.; Yeung, Y.A.; Sutton, J.; Hamze, M.; Valton, J.; Smith, J.; Djuretic, I.; et al. Allogeneic FLT3 CAR T Cells with an Off-Switch Exhibit Potent Activity against AML and Can Be Depleted to Expedite Bone Marrow Recovery. Mol. Ther. 2020, 28, 2237-2251. [CrossRef] 